Canadian

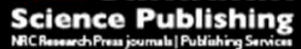

Canadian Journal of Forest Research Revue canadienne de recherche forestière

\title{
Ground-dwelling arthropod response to fire and clearcutting in jack pine: implications for ecosystem management
}

\begin{tabular}{|c|c|}
\hline Journal: & Canadian Journal of Forest Research \\
\hline Manuscript ID & cjfr-2017-0145.R1 \\
\hline Manuscript Type: & Article \\
\hline Date Submitted by the Author: & 04-Aug-2017 \\
\hline Complete List of Authors: & $\begin{array}{l}\text { Venier, Lisa; Natural Resources Canada, Canadian Forest Service } \\
\text { Work, Timothy; Departement des Sciences Biologiques, Departement des } \\
\text { Sciences Biologiques } \\
\text { Klimaszewski, Jan; Natural Resources Canada, Canadian Forest Service } \\
\text { Morris, Dave; Ontario Ministry of Natural Resources, Centre for Northern } \\
\text { Forest Ecosystem Research } \\
\text { Bowden, Joseph; Natural Resources Canada, Canadian Forest Service } \\
\text { Kwiaton, Martin; Ontario Ministry of Natural Resources and Forestry, } \\
\text { Centre for Northern Forest Ecosystem Research } \\
\text { Webster, Kara; Natural Resources Canada, Canadian Forest Service } \\
\text { Hazlett, Paul; Natural Resources Canada, Canadian Forest Service }\end{array}$ \\
\hline Keyword: & $\begin{array}{l}\text { natural disturbance emulation, ecosystem management, carabid beetle, } \\
\text { rove beetle, ground spider }\end{array}$ \\
\hline $\begin{array}{r}\text { Is the invited manuscript for } \\
\text { consideration in a Special } \\
\text { Issue? : }\end{array}$ & N/A \\
\hline
\end{tabular}




\section{Ground-dwelling arthropod response to fire and clearcutting in jack}

\section{2 pine: implications for ecosystem management}

3

4 Venier, L. A. ${ }^{a}$ Work, T.T. ${ }^{b}$, Klimaszewski, J. ${ }^{c}$, Morris, D.M. ${ }^{d}$, Bowden, J. ${ }^{e}$, Kwiaton, M.M. ${ }^{f}$, Webster, ${ }^{\mathrm{g}}$, 5 Hazlett, P. $^{\mathrm{h}}$

6

$7 \quad{ }^{\text {a }}$ Corresponding author. Canadian Forest Service, Natural Resources Canada, Great Lakes Forestry

8 Centre, 1219 Queen St. E. Sault Ste. Marie, Ontario, P6A 2E5, Canada, lisa.venier@canada .ca

9

$10{ }^{b}$ Département des Sciences Biologiques, Université de Québec à Montréal, C.P. 8888, Succursale

11 Centre-ville, Montréal, Québec, H3P 3P8, Canada, work.timothy@uqam.ca

12

$13{ }^{\mathrm{c} C}$ Canadian Forest Service, Natural Resources Canada, Laurentian Forestry Centre, 1055 Ave du P.E.P.S.,

14 P.O. Box 10380, Stn. Sainte-Foy, Quebec, Quebec, Canada, G1V 4C7, jan.klimaszewski@canada.ca

15

$16{ }^{d}$ Centre for Northern Forest Ecosystem Research, 421 James St. South, Thunder Bay, Ontario, P7E 2V6,

17 Canada, dave.m.morris@ontario.ca

18

$19{ }^{\mathrm{e}}$ Canadian Forest Service, Natural Resources Canada, Atlantic Forestry Centre, Corner Brook Office, P.O.

20 Box 960, 26 University Drive, Corner Brook, NL, Canada, A2H 6J3, joseph.bowden@canada.ca

21

$22{ }^{f}$ Centre for Northern Forest Ecosystem Research, 421 James St. South, Thunder Bay, Ontario, P7E 2V6, 23 Canada, martin.kwiaton@ontario.ca 
$25{ }^{\mathrm{g}}$ Canadian Forest Service, Natural Resources Canada, Great Lakes Forestry Centre, 1219 Queen St. E.

26 Sault Ste. Marie, Ontario, P6A 2E5, Canada, kara.webster@canada.ca

27

$28{ }^{\mathrm{h}}$ Canadian Forest Service, Natural Resources Canada, Great Lakes Forestry Centre, 1219 Queen St. E.

29 Sault Ste. Marie, Ontario, P6A 2E5, Canada, paul.hazlett@canada.ca

30

31 
32 Abstract

33 We tested the response of species composition of three dominant litter-dwelling arthropod taxa

34 (carabid beetles, spiders, and rove beetles) to wildfire and harvest. This study was conducted in

35 northcentral Ontario $\left(47^{\circ} 42^{\prime} \mathrm{N}, 83^{\circ} 36^{\prime} \mathrm{W}\right)$ in jack pine dominated stands in 2013 using pitfall trapping.

36 Using 222 species (12, 015 individuals), we compared effects of disturbance using recently burned (3

37 years post-fire) and clearcut sites (3-years post-harvest; tree-length, full-tree, stump removal and

38 blading) as well as older, closed-canopy stands that have regenerated following clearcutting (51 years

39 post-harvest) and fire (92 years post-fire), with multivariate regression trees. Taxa were more similar in

40 the three controls (including recent fire) than to harvested treatments with increased forest floor

41 disturbance in harvested plots being a likely explanation. In addition, taxa were different in the younger

42 (51 years) harvest origin plots than the older (92 years) fire origin plots suggesting that communities had

43 not yet recovered from the harvest disturbance possibly due to insufficient coarse woody debris in the

44 younger stand. These results indicate that forest management practices that match natural forest floor

45 disturbance could ameliorate short-term effects whereas the maintenance of more coarse woody debris

46 could reduce the recovery time of epigaeic communities.

47

48 Keywords: natural disturbance emulation, ecosystem management, carabid beetle, rove beetle, ground 49 spider.

50

51 


\section{Introduction}

Ecological comparisons of resident biota between managed and naturally disturbed sites are the premise of natural-disturbance based approaches to forest management. Natural disturbance-based management is founded on the assumption that forestry practices that emulate aspects of natural disturbance will reduce the negative impacts of forest management on biodiversity (Hunter 1993, Bergeron et al. 2002, Long 2009). Forest ecosystem management aims to maintain and enhance the long-term health of our forests including biodiversity (Gauthier et al. 2009) which requires a thorough understanding of the ecological impacts of alternative forest management options and their relationship to both mature and naturally disturbed forests. Assessments of how biodiversity under alternative forest management practices compare to biodiversity under fire disturbance and in mature forest conditions provides necessary information to select and adjust practices to best match a natural disturbance regime within an adaptive management framework.

Wildfire and clearcutting are dominant disturbances in jack pine (Pinus banksiana Lamb.) forests with differential impacts on residual standing overstory and forest soils that may have lasting effects on resident biodiversity. In the absence of forest management, jack pine forests are subject to frequent and often highly variable severity fires (Bergeron et al. 2001). Variation in fire severity creates a range of conditions for resident biota where overstory mortality and exposure of mineral soil typically increase with fire severity (Weber et al. 1987, Greene et al. 2004) and where deadwood is initially abundant postfire (Brais et al. 2005). In contrast, overstory removal and soil disturbance following site preparation to improve jack pine regeneration success are comparatively more intense and more uniform following clearcutting (McRae et al. 2001). Forest floor disturbances and reductions in deadwood are intensified when clearcutting is coupled with additional removal of residual forest biomass (ie. branches, tops, stumps) with potential to be used as bioenergy feedstocks (Thiffault et al. 2011, 2014). The extent to which forest biota are initially affected by fire and clearcutting and the persistence of impacts dictate 
whether clearcutting and increasingly intensive variants associated with bioenergy harvest should be viewed as ecologically sustainable in these forests.

Despite the prominence of jack pine in North American boreal forests (Suffling et al. 1982) and continued assertions that clearcutting emulates certain attributes of wildfire (OMNR 2013), empirical comparisons of resident biodiversity following both clearcutting and fire in jack pine have been limited to longer-term responses of bryophytes, vascular plants (Reich et al. 2001) and initial responses of moths post-disturbance (Chaundy-Smart et al. 2012). Vascular plant composition did not differ between stands that had burned or had been logged in regenerated stands (ca. 30-90 years post disturbance) with a standing overstory (Reich et al. 2001). For moths in stands with a shorter disturbance history (ca. 5 years), clearcuts and wildfires maintained a similar suite of dominant species, similar overall diversity of moths and differed only in relative abundance of 12 (of 240) species (Chaundy-Smart et al. 2012). Taken together these results provide some initial evidence that for plants and organisms that rely directly on plants, clearcutting may indeed sufficiently emulate fire in jack pine stands.

However in boreal stands dominated by tree species other than jack pine, differences in biodiversity between clearcuts and wildfire are more pronounced particularly in groups such as grounddwelling arthropods (Niemelä et al. 1993, Buddle et al. 2000, 2006, Pohl et al. 2007, Work et al. 2010), and this research suggests that impacts of clearcutting should be limited and faunal convergence of ground-dwelling arthropods should be observed once the post-disturbance overstory and nutrient cycling have re-established. Clearcutting is, however, a silvicultural prescription that can involve different intensities of site preparation and soil disturbance in addition to overstory removal. For tree species that require exposure of mineral soil to ensure successful regeneration (such as many conifer species);clearcutting prescriptions may include additional measures that create favourable seed beds and plantable microsites (Munson et al. 1993, Munson and Timmer 1995). Following clearcutting of jack pine, soils are often mechanically site prepared to create a favourable environment for seed 
100

101

102

103

104

105

106

107

108

109

110

111

112

113

114

115

116

117

118

119

120

121

122

123

germination or seedling establishment and survival (OMNR 1997, Ryans and Sutherland 2001) In some

instances, site preparation such as scarification has caused further reductions in abundance and species richness and compositional changes of litter arthropods beyond those with only overstory removal (Klimaszewski et al. 2005). Thus for litter dwelling arthropods, the effects of clearcut prescriptions in jack pine may be a combination of both overstory removal and additional impacts related to mechanical site preparation.

With increased interest in climate change mitigation and the development of forest-based bioenergy feedstocks, clearcutting in jack pine may be intensified to include additional removal of logging residuals and stumps. Outside of North America, logging residuals and stumps are increasingly used as bioenergy to reduce dependence on fossil carbon (Hakkila 2004, Björheden 2006). Within North America, declining markets for traditional wood products and the relative abundance of jack pine have led to similar interest in additional recovery of forest biomass following clearcutting (Kwiaton et al. 2014). Post-harvest removal of forest biomass in jack pine stands has been shown to cause major compositional shifts in litter-dwelling arthropods initially 1 and 2 years post-harvest (Work et al. 2014). However, these impacts of biomass removal have yet to be verified in part due to the lack of older stands that have regenerated following biomass removal. It follows that assemblages in sites with additional soil disturbance and reduced deadwood availability are more likely to fall outside the range of natural variability observed in recently burned stands and that these initial differences in composition may contribute to more persistent impacts of clearcutting in jack pine forests.

We assessed the short-term ( 3 years post-harvest) impacts of clearcutting with increasing levels of biomass removal and the longer-term (51 years post-harvest) persistence of the effects of clearcutting in jack pine on three dominant groups of leaf-litter arthropods (ground beetles, spiders and rove beetles) relative to a recent burn (3-years old) and an 92 year-old stand of pyrogenic origin. We hypothesized that (1) the initial effects of clearcutting on epigaeic assemblages will differ from the initial 
124 impacts of wildfire, (2) that increasing removal of residual biomass will further exacerbate differences in

125 species composition through the compounded effects of loss of coarse wood and increasing soil

126 disturbances, and (3) that effects of clearcutting will largely be abated once the overstory has re-

127 established and that faunal composition of litter arthropods will be similar in mature stands originating

128 from clearcutting and wildfire.

2. Methods

2.1 Study Area

We collected litter arthropods from a) harvested plots in a clearcut ( 2.5 years post-harvest) and unharvested plots in a 51-year old jack pine stand (Young Control) which was previously clearcut and located at the Island Lake Biomass Harvest Experiment approximately $20 \mathrm{~km}$ from Chapleau, Ontario,

137 Canada $\left(47^{\circ} 42^{\prime} \mathrm{N}, 83^{\circ} 36^{\prime} \mathrm{W}\right.$; Kwiaton et al. 2014), b) a recent fire (Recent Fire; 3 years post-fire) located 138 near Ripple Lake, Ontario $\left(47^{\circ} 56^{\prime} \mathrm{N}, 84^{\circ} 09^{\prime} \mathrm{W}\right.$ ) and c) a 92-year old jack pine stand (Old Control) of 139 pyrogenic origin $\left(47^{\circ} 38^{\prime} \mathrm{N}, 83^{\circ} 15^{\prime} \mathrm{W}\right)$ (Figure 1). Mean annual temperature and precipitation for the area is $1.7^{\circ} \mathrm{C}$ and $797 \mathrm{~mm}$ (532 $\mathrm{mm}$ of rainfall and $277 \mathrm{~cm}$ of snowfall), respectively (Environment

141 Canada 2013). These three jack pine-dominated stands (>90\% jack pine, based on live tree basal area)

142 all established on glaciofluvial, coarse-textured, glacial outwash deposits characterized by sandy

143 (medium sand) parent material overtopped with a variable depth loess (windblown) cap of finer

144 textured soil (silty fine sand to silt loam) (Table 1). The forest floor was thinner at the recently burned 145 site $(5.4 \mathrm{~cm})$ compared to the other two sites $(9-10 \mathrm{~cm})$ due to partial consumption during the wildfire 146 event. Both stand density and tree volume prior to the stand-replacing wildfire were lower in the Recent 147 Fire plantation compared to the other sites as it was a younger stand ( 30 -yr-old) at the time of the fire. 
148 The fire did result in much higher amounts of standing dead trees $\left(107.4 \mathrm{~m}^{3} \mathrm{ha}^{-1}\right)$ and moderate levels of 149 DWD $\left(41.6 \mathrm{~m}^{3} \mathrm{ha}^{-1}\right)$, measured three years after the fire. The Old Control (OC) site had moderate levels 150 of standing dead volume $\left(37.9 \mathrm{~m}^{3} \mathrm{ha}^{-1}\right)$ and much higher volumes of DWD $\left(76 \mathrm{~m}^{3} \mathrm{ha}^{-1}\right)$ compared to the 151 low levels of dead wood in the Young Control (YC) at Island Lake, as the Old Control stand is showing 152 signs of the onset of stand breakup. The proportion of deadwood assigned to the different decay 153 classes also differed slightly between sites. Most notable, was the high amount of decay class 5 dead 154 wood at the Island Lake site, a legacy of the previous tree length harvest done in 1959. In general these 155 stands are very comparable; having jack pine dominant overstories, comparable tree densities and very 156 similar soil characteristics (Table 1). Their primary differences are related to the treatment effects. The Island Lake Biomass Harvest Experiment was a second growth jack pine stand that was originally clearcut harvested in the fall of 1959. The site was scarified and hand seeded in 1960 but due to poor initial regeneration was replanted in 1962. Harvesting and biomass removal treatments were applied in 2011 and standing dead trees were toppled prior to biomass removal (Kwiaton et al 2014).

161 Four intensities of biomass removal were applied in a randomized complete block design. From least to 162 most severe removal, the treatments were: (1) Tree-length harvest (TL), where boles were delimbed, cut 163 at $10 \mathrm{~cm}$ diameter and removed and residual slash was distributed evenly throughout the treatment 164 using an excavator; (2) Full-tree biomass harvest (FT), where the bole with branches of all merchantable 165 and unmerchantable trees were removed and delimbed outside experimental plots; (3) Stump removal 166 (FTS) where bole and branches were removed as per full-tree harvest and stumps with large attached 167 roots were removed using an excavator and placed at least $10 \mathrm{~m}$ beyond the experimental plot; and (4) 168 Blading (FTB), where boles and branches were removed as per full-tree harvest and stumps, residual 169 coarse woody material and the forest floor were removed with a excavator fitted with large metal blade.

170 The tree-length harvest, full-tree harvest and stump removal treatments were all site prepared post-

171 harvest using disc trenching with $2.1 \mathrm{~m}$ spacing between trench centres. Disc trenching results in 'flat' 
172 undisturbed linear areas with $15 \mathrm{~cm}$ deep trenches on either side and linear piles of mixed organic and

173 mineral soil beside the trenches (spoils). Each experimental treatment was replicated 5 times and each

174 experimental plot was $70 \times 70 \mathrm{~m}$ (0.49 ha). Experimental plots were separated by at least $20 \mathrm{~m}$ from

175 each other and the surrounding uncut forest. Associated with these experimental plots are 5 sampling

176 plots $(70 \times 70 \mathrm{~m})$ located directly adjacent to the harvested area in the same stand originated from

177 clearcutting 51 years ago (Young Control $=\mathrm{YC}$ ). These plots were spaced approximately $20 \mathrm{~m}$ from one

178 another. This area has the same stand conditions as the experimental plots prior to cutting (Table 1).

179 We compared litter arthropods collected from the harvested treatments (TL, FT, FTS, FTB) and

180 the Young Control (YC) to those collected from two locations that had been disturbed by wildfire. The

181 first location was a recent wildfire $55 \mathrm{~km}$ north-west of the Island Lake Biomass Harvest Experiment

182 (Recent Fire). Prior to burning, this 20 ha stand was a 30 year-old monoculture jack pine stand that

183 originated from clearcutting, seeding and planting. In spring of 2010, an intense crown fire resulted in

184 almost full mortality but resulted in relatively little exposed mineral soil compared to fires of this

185 intensity due to high surface and soil moisture conditions. Within this stand we sampled arthropods

186 from 6 experimental plots spaced $20 \mathrm{~m}$ apart. Arthropods collected from this stand reflect the

187 immediate impacts of overstory kill by fire as well as any longer-term impacts enduring from the initial

188 clearcut. We also collected litter arthropods from a 92 year-old jack pine stand of pyrogenic origin

189 located ca. $20 \mathrm{~km}$ southeast of the Island Lake Biomass Harvest Experiment (Figure 1). Within the stand 190 we sampled arthropods from 5 experimental plots spaced $20 \mathrm{~m}$ apart. Arthropods collected from this

191 stand reflect community composition in the absence of clearcutting and serve as a benchmark for

192 comparison with harvested sites.

193 Our forest harvest treatments are set up as a randomized block design but we acknowledge that

194 our controls represent pseudo-replicates. This is a common occurrence in operational-scale studies

195 when comparing harvest treatments to control conditions, especially wildfire controls due to limitations 
196

197

198

199

200

201

202

203

204

205

206

207

208

209

210

211

212

213

214

215

216

217

218

219

in the availability and accessibility of appropriate controls. There is however, still value in making comparisons among single stands, especially when the underlying characteristics of stands can be shown to be very similar as is the case here. Assessments of how biodiversity under alternative forest management practices compare to biodiversity under fire disturbance and in mature forest conditions provide valuable information to assess and adjust practices to best match a natural disturbance regime within an adaptive management framework. Hence, the current study provides valuable insight into how epigaeic communities respond to alternative disturbances and time since initiation.

\subsection{Pitfall Trapping}

Arthropods were collected every two weeks using pitfall traps (diameter $11.5 \mathrm{~cm}$, depth $4.5 \mathrm{~cm}$ ) between 15 May and 19 August 2013. Traps were filled with $150 \mathrm{ml}$ of propylene glycol as a preservative, $150 \mathrm{ml}$ of water and a small amount of detergent to break water surface tension. Traps were covered with suspended white plastic covers to prevent flooding from rain. Eight traps were placed in each experimental plot (Figure 2). In TL, FT and FTS harvested plots traps were always placed on the undisturbed flats (i.e., not in the trenches or on the spoils). Each collection period, trap contents were emptied into a Whirl Pack bag in the field and returned to the laboratory for sorting. Specimens were sorted into three major taxa: carabid beetles (Coleoptera: Carabidae), spiders (Araneae) and rove beetles (Coleoptera: Staphylinidae) and stored in $70 \%$ ethanol. These three groups are among the most abundant macroarthropods on the forest floor and have been used to assess the ecological impacts of a wide variety of natural disturbances and silvicultural interventions including wildfire and salvage logging (Koivula and Spence 2006, Martikainen et al. 2006), clearcut and partial cut harvesting (Work et al. 2008, Work et al. 2010, Paradis and Work 2011, Graham-Sauvé et al. 2013) and biomass removal (Work et al. 2013, Work et al. 2014). All specimens were identified to species. Carabid species were identified 
220

221

222

223

224

225

226

227

228

229

230

231

232

233

234

235

236

237

238

239

240

241

242

243

according to Lindroth (1961-1969), following the nomenclature of Bousquet and Larochelle (1993).

Spiders were identified to species according to Paquin and Duperre (2003) and references in the World Spider Catalog (2017). Rove beetles were identified primarily according to Ashe (2001), Brunke et al. (2011) and Seevers (1978).

\subsection{Environmental Variables}

Surface coarse deadwood (DW) was measured using three fixed area sub-plots (rectangular, 15m x 2m) within each of the control (FC, YC, OC) plots. The first sub-plot originated from the treatment plot centre oriented with a random azimuth. The subsequent sub-plots were each offset $120^{\circ}$ to form a triangle. The harvest treatment plots (TL, FT, FTS, FTB) were measured using the above technique in pre-harvest plot assessments combined with 12 fixed area sub-plots (circular, $15 \mathrm{~m} \times 1 \mathrm{~m}$ ) conducted after the harvest treatments that captured fresh post-harvest slash that contributed to the total DW pool. DW from the pre-harvest assessment in decay classes 1 and 2 was subtracted from the post-harvest assessment to avoid double counting of DW material at the plot level. Each DW piece ( $>5 \mathrm{~cm}$ diameter) within the subplots was tallied for species, decay class (DC), length within the sub-plot boundaries, and end diameters. Decaying stumps were also recorded (species, DC, height, diameter). Decay class determinations followed the classification described by Naesset (1999): 1) Recently dead tree, bark intact 2) bark mostly intact, wood of outer layers (sapwood) of the log has started to soften due to rot, 3) bark sloughing or absent, soft outer layers of log and are easily removed with a knife, heartwood mostly sound, 4) bark detached, wood soft, no solid core, 5) Fragmented, no structural integrity. Surface deadwood volume was calculated for each piece using the average diameter and length, with the assumption that pieces were cylinders, and converted to $\mathrm{m}^{3} \mathrm{ha}^{-1}$ using the subplot area $(10000 / 30$

$\mathrm{m}^{2}$ ). To estimate the amount of buried wood (>90\% of log covered by live moss), a narrow trench ( $15 \mathrm{~m}$ 
244 in length) that bisected each subplot was dug through the organic layer to expose all buried DW. Each

245 piece of buried DW that was encountered along the trench was tallied for its intersecting diameter.

246 Total buried wood volume for each trench was calculated following the line intersect sampling approach

247 of Marshall et al. (2000)

248

$$
y_{i}\left[m^{3} h a^{-1}\right]=\frac{\pi^{2}}{8 \times L} \times \sum_{j=1}^{m_{i}} d_{i j}^{2}
$$

249 Where $y_{i}$ is the total volume per hectare based on transect $i, L$ is the length of the trench, and $d_{i j}$ is he 250 diameter at the point of intersection of individual buried wood pieces $j$ to $m$. Total volume per trench was then averaged for each treatment plot.

Microclimate was measured between 24 May and 6 October 2014 in 2 of 5 replicate plots of each harvest treatment and in one location in each of the young control, old control and the recent fire

254 sites. The coverage of microclimate data was inconsistent in 2013 (the year of arthropod collection, so 255 we present here the data from 2014 to illustrate the differences in microclimate between treatments.

256 We expect that the relative microclimate between treatments was reasonably constant between 2013 257 and 2014 but have not included these data in any formal analyses. Temperature was measured using 258 copper constantan thermocouples at $15 \mathrm{~cm}$ above the forest floor, at the forest floor (interface between 259 organic and mineral soil; not available for bladed plots) and at $10 \mathrm{~cm}$ below the soil surface. Campbell 260 Scientific CS616 Water Content Reflectometers (WCR) measured soil moisture at $10 \mathrm{~cm}$ below the soil 261 surface. Soil and air temperatures were read by the datalogger every 2 min and averaged and stored 262 every hour. Mean, minimum and maximum daily temperatures and moisture content were calculated 263 for each treatment. Mean soil temperature $\left({ }^{\circ} \mathrm{C}\right)$ and moisture content (\%water by volume) were plotted 264 over time to show seasonal variation in measures. We also plotted the daily temperature range 265 (maximum-minimum) over the season for each treatment. 
Mineral soil exposure was measured on $4 \mathrm{~m} \times 4 \mathrm{~m}$ assessment plots around each pitfall trap. Each

267 assessment plot was divided into 4 quadrats. In each quadrat, we estimated the percent cover of

268 mineral soil exposure that resulted from site preparation, from the stumping treatment (stump and root

269 removal), complete burning of forest floor, and any other mineral soil exposure (e.g., overturned stumps

270 etc.).

271

$272 \quad 2.4$ Analysis

273

We standardized trap catches by the total number of trap days for each trapping location. We

275 used multivariate regression trees (MRTs; De'ath 2002) to compare assemblages of each of the three

276 groups to treatment using the mvpart package in R (De'ath 2011). MRTs are hierarchical models that

277 successively split data into more homogeneous groupings based on a set of explanatory variables. This

278 approach makes relatively few underlying assumptions about statistical distributions within the data

279 and, thus is widely applicable to assemblage data with many species such as the three taxa used herein.

280 We used sum-of-squares multivariate regression trees (ssMRT) to characterize species assemblages as a

281 function of treatment. We selected the final tree size based on cross-validated errors. Following De'ath

282 (2002), we selected the smallest tree whose cross validation error fell within one standard deviation of

283 the minimum cross-validated relative error. Response to treatments was interpreted with reference to

284 overstory removal, amount of above ground deadwood, microclimate on and below the soil surface, and

285 mineral soil exposure as a measure of forest floor disturbance. All analyses were done using R version

$286 \quad 2.12 .2$ (R Development Core Team, 2011).

We used mixed effects models (R Ime4 package; Bates et al. 2015) and Tukey's multiple

288 comparisons (R Multcomp package; Hothorn et al. 2008) to examine the differences in coarse woody 
debris volumes and mineral soil exposure between treatments. We could not analyse differences in

290 microclimate between treatments as we only had measurements in 2 replicates of each treatment.

291

292

3. Results

We captured 12,015 individuals in 2013, of which 5923 were ground beetles represented by 34 297 species (Appendix 1), 4861 were spiders represented by 118 species (Appendix 2) and 1231 were rove 298 beeltles represented by 70 species (Appendix 3). The most common ground beetles were Pterostichus 299 adstrictus (34\%), Pterostichus pensylvanicus (12\%), and Poecilius lucublandus (12\%) representing $58 \%$ 300 of all individuals captured (Appendix 1). The most frequently collected spider species were Pardosa 301 xerampelina (17\%), Pardosa moesta (15\%) and Amaurobius borealis (11\%), representing $43 \%$ of all 302 spiders captured (Appendix 2). The most common rove beetles were Atheta capsularis (14\%),

303 Mycetoporus consors (10\%) and Lordithon fungicola (8\%) representing $32 \%$ of all rove beetles captured 304 (Appendix 3). The number of trap days for each plot ranged from 664 to 776 depending on the amount 305 of trap disturbance.

\subsection{Carabid beetles}

The total variance explained by the carabids MRT was $77.64 \%$ (Table 2). The most important species for explaining the variance in the regression trees were Pterostichus adstrictus (25.8\%), Poecilius

311 lucublandus (16.4\%) and Pterostichus coracinus (6.5\%) (Table 2). The most significant results from the 312 ground beetle MRT were the first split of all controls from all the harvested treatments i.e., the fire is 
313

314

315

316

317

318

319

320

321

322

323

324

325

326

327

328

329

330

331

332

333

334

335

336

more similar to the uncut sites than to the harvested sites, the split of the bladed treatment from the other harvest sites (this extreme treatment seems to negatively impact the carabid community), and the lack of a split between full-tree and tree-length treatments (the full-tree biomass harvest does not appear to exceed any threshold for response to biomass removal).

The left hand side of the MRT contain the 3 controls. The first split, separating harvested plots from uncut plots (including fire) explained $36.7 \%$ of the variance (Table 2; Figure 3a). Five carabid species accounted for most of this variance (Poecilius lucublandus (15.2\%), Pterostichus adstrictus (11.9\%), Harpalus plenalis (2.8\%), Harpalus laticeps (1.8\%), and Sphaeroderus stenostomus (1.4\%)) for a total of $33.1 \%$ variance (Table 2). Of these, the first four were associated with harvested plots whereas S. stenostomus was associated with the uncut stands (Figure 4a). Split 2 separates fire from the uncut stands and explained $11.3 \%$ of the variance with Pterostichus coracinus (3.6\%), Sphareoderus stenostomus (2.0\%), Myas coracinus (1.3\%) explaining the bulk of the variance (6.9\%), all of which were rarely found in the fire plots (Table 2 , Figures $3 a, 4 a)$. Harpalus laticeps $(0.87 \%)$ was often associated with the fire plots (Table 2, Figure 4a). The fourth split contrasts the young plantation control with the mature fire-origin controls (2.8\%) (Table 2, Figure 3a). Myas coracinus (1.0\%) was associated with the young plantation control (Table 2, Figure 4a). There do not appear to be any species that were strongly associated with the mature fire-origin control in comparison to the plantation (Figure 4a).

The right hand side of the MRT deals with the harvested treatments. The third split separated the bladed plots from the other harvested plots (22.8\%) (Table 2, Figure 3a). Five species accounted for greater than $1 \%$ of variance each and include Pterostichus adstrictus (12.1\%), Pterostichus coracinus (1.8\%), Synuchus impunctatus (1.5\%), Pterostichus pensylvanicus (1.4\%) and Poecilius lucublandus (1.2\%) for a total of $18 \%$ (Table 2, Figure 4a). All of these species were associated with the harvested but not bladed plots except for Poecilius lucublandus (Figure 4a). In addition, Bembidion nitidum (.61\%), Harpalus affinis $(.65 \%), H$. fuliginosus $(.19 \%), H$. laticeps $(0.87 \%)$ and $H$. pensylvanicus $(0.47 \%)$ were all 
337

338

339

340

341

342

343

344

345

346

347

348

349

350

351

352

353

354

355

356

357

358

359

360

more common in bladed plots (Table 2, Figure 4a). The $5^{\text {th }}$ split contrasted the stumped plots with the full-tree biomass and tree-length plots (4.0\%) (Table 2; Figure3a). The full-tree biomass and tree-length treatments did not split in the MRT.

\subsection{Spiders}

The spider MRT was very similar to the ground beetle MRT except that the stumped treatment did not split from tree-length and full-tree biomass treatment and the young control split into two groups (east plots vs west plots). The total variance explained by the spider MRT is $63.96 \%$ (Table 3 ). The majority of the variance in the tree was explained by Pardosa moesta (15.47\%), Pardosa xerampelina (13.90\%), Amaurobius borealis (7.63\%), Pardosa hyperborea (7.11\%), Trochosa terricola $(5.89 \%)$ and Pardosa distincta (5.01\%) (Table 3; Figure 3b, 4b). This split (controls on the left and harvest plots on the right) explained $30.52 \%$ of the variance (Table 3 ). Three species were strongly associated with this split (Pardosa moesta, P. xerampelina, and P.distincta) all three of which were associated with the harvested sites (Figure 4b). Several species appeared to be more associated with the controls including Cybaeopsis euopla (0.40\%), Pardosa hyperborea (0.65\%), and Trochosa terricola (1.73\%) (Table 3, Figure 4b). The second split explained $11.98 \%$ of variance, splitting the fire from the young and old controls. Here the most important species were Trochosa terricola (2.11\%), Amaurobius borealis (2.04\%), Sciastes truncatus (1.72\%), which were all associated with old and young controls, and Pardosa xerampelina (1.46\%) which was associated with fire (Table 3; Figures 3b,4b). The fourth split separated the old control treatment from the young control treatment (5.76\%)(Table 3; Figure 3b). It appeared that Pardosa hyperborea was driving this split (3.18\%) which was strongly associated with the young control (Table 3; Figure 4b). The fifth split separates the eastern most plots (control plots 1 and 2) of the young control from the western most plots (control plots 3-5). Although all of the control plots are situated 
$361>40 \mathrm{~m}$ from the harvest edge within a large, contiguous tract of the undisturbed stand, there were

362 notable differences in aboveground DWD volumes (plots 1-2: $23.1 \mathrm{~m}^{3} \mathrm{ha}^{-1}$ versus plots 3-5: 3.4 $\mathrm{m}^{3} \mathrm{ha}^{-1}$ )

363 and forest floor depth (plots 1-2: $10.9 \mathrm{~cm}$ versus plots 3-5: $6.3 \mathrm{~cm}$ ) between the eastern versus western 364 plots that may have contributed to this split in the MRT.

365 The third split (9.16\%) separated bladed plots from other harvested plots (Figure3b, 4b).

366 Important species in this split include Amaurobius borealis (1.55\%), Pardosa moesta (1.41\%) and $P$.

367 xerampelina (1.14\%) (Table 3). All three of these species were more strongly associated with non-

368 bladed sites (Figure 4b). This appeared to be true for the vast majority of spider species (Figure 4b). No 369 species showed a clear preference for bladed plots (Figure 4b).

\subsection{Rove beetles}

The rove beetle MRT had some similarities to the other MRTs in that harvest treatments split

373 early from controls, the bladed treatment split from other harvest treatments and the full-tree biomass

374 and tree-length did not split. The primary difference for rove beetles is that the old control split from all

375 other treatments in the first split. The total variance explained by this regression tree is $71.52 \%$ (Table

376 4). The most important species were Atheta capsularis (13.99\%), Atheta strigosula (8.94\%), Lordithon

377 fungicola (7.97\%), Oxypoda grandipennis (6.99\%), Atheta remulsa (4.53\%) and Aleochara fumata

378 (3.37\%) (Table 4). The first split of the tree explained $57.73 \%$ of variance with all of the above species

379 being important except for Aleochara fumata (Table 4; Figures 3c, 4c). In this split the vast majority of

380 species and individuals were associated with the old control, very few individuals were captured in the

381 other 6 treatments (Figure 4c). Of the 1231 individuals captured, 745 were captured in the 5 old control

382 plots whereas only 486 were captured in all plots of the other 6 treatments combined. Only two species

383 were associated with the other treatments including Aleochara fumata (0.32\%) and Mycetoporus

384 consors $(0.70 \%)$ ( Table 4$)$. In the second split, fire and the young control treatment separated from the 
harvest treatments in a similar fashion to carabid beetles and spiders (Figure 3c). The fourth split separated bladed from the other harvest treatment which was also consistent with the other two taxa (Figure 3c). The old control treatment plots do split into northern (plots 1-3) versus southern (plots 4 and 5) plots. In this case, the southern plots had greater amounts of buried dead wood (plots 4-5: 39.9 $\mathrm{m}^{3} \mathrm{ha}^{-1}$ versus plots 1-3: $\left.10.2 \mathrm{~m}^{3} \mathrm{ha}^{-1}\right)$ and greater amounts of aboveground DWD in larger $(>14 \mathrm{~cm})$ diameter classes (plots 4-5: $34.2 \mathrm{~m}^{3} \mathrm{ha}^{-1}$ versus plots 1-3: $10.2 \mathrm{~m}^{3} \mathrm{ha}^{-1}$ ).

\subsection{Environmental Variables}

The four harvest treatments showed a gradient of CWD from about $40 \mathrm{~m}^{3} \mathrm{ha}^{-1}$ in the tree length treatment to no CWD in the bladed treatment. The old control treatment had by far the most CWD at about $70 \mathrm{~m}^{3} \mathrm{ha}^{-1}$, whereas the young control treatment had very little CWD $\left(\sim 5 \mathrm{~m}^{3} \mathrm{ha}^{-1}\right)$, which was less than in the full-tree harvest treatments. In contrast, the recent fire had similar CWD as the tree-length treatment (Figure 5; Appendix 1). Overall, the mixed effects model demonstrated significant differences in CWD between treatments ( $D F=6, F=10.68, P<0.0001)$ but Tukey multiple comparisons indicate that significant differences are primarily between the old control $(O C)$ and other treatments although the recent fire (RF) also showed some differences with the more intense harvest disturbances (Appendix 2). Percent mineral soil exposure was measured as an indicator of forest floor disturbance (Figure 6; Appendix 1). Mineral soil exposure showed a strong gradient from little or no disturbance in the old and young controls, some minimal disturbance in the recent fire and increasing mineral soil exposure from tree-length ( $15 \%$ exposure) to the bladed treatment plots (90\% exposure) (Mixed Effects Model: $D f=6, F=162.93, P<0.0001$, Figure 6). Tukey's multiple comparisons found significant differences between all treatments except the controls (OC, YC, RF), and between full-tree and tree-length harvest (FT-SO) (Appendix 2). 
409 below the soil surface and the moisture at $10 \mathrm{~cm}$ below the soil surface (Figures $7 \mathrm{a}, \mathrm{b}, \mathrm{c}$ ), as well as the

410 air temperature at $15 \mathrm{~cm}$ and the daily range in soil temperature at $10 \mathrm{~cm}$ below soil surface. For

411 mineral soil temperature it was clear that the old and young controls were generally cooler than the

412 other treatments through most of the frost-free season, particularly during the arthropod collection

413 period. Later in the season the treatments became more similar. The fire and the 3 least disturbed

414 harvest treatments showed a similar pattern to one another. The bladed plot was much warmer than all

415 other treatments throughout the arthropod collection period. Early in the season, the bladed plot was

416 as much as 12 degrees warmer. By the end of the sampling period (Julian day 231), the difference was

417 closer to 2 degrees (Figure 7b). The air temperatures were highly variable over the short term (8 to 10

418 degree variation over 5 day span) but very similar between treatments (data not shown), and soil

419 temperatures in bladed plots were more variable within days (data not shown) and over short time

420 frames(up to 5 degrees over 5 days for bladed plots versus one to two degrees over 5 days for other

421 treatments; Figure 7b). Patterns between treatments for forest floor temperature were similar to $10 \mathrm{~cm}$

422 below soil surface but our data exclude the bladed plots because there was no organic-mineral soil

423 interface to place the probe. Soil moisture patterns wee quite different from temperature. The fire plot

424 was much drier than all other treatments (up to $15 \%$ lower in water by volume relative to old and young

425 control and between 1 and $10 \%$ lower relative to harvest treatments depending on time of season).

426 Generally the old and young controls remained moister than the harvested plots from the middle of

427 June through to the middle of September (sometimes by as much as $10 \%$ or as little as $1 \%$ ).

428

4. Discussion 
All three taxa investigated in this study showed similarities in their response to the seven

432 treatments examined here, with some notable exceptions. All three taxa had communities that were

433 more similar in the three controls (including fire) than to harvested treatments with increased forest

434 floor disturbance in harvested plots being a possible explanation. Lack of similarity of arthropod

435 communities between the recent fire and the harvest treatments suggests that natural disturbance

436 emulation could be improved, and confirms the first hypothesis that initial effects of harvesting differed

437 from the initial effects of fire for these three taxonomic groups. Within our harvest treatments, tree-

438 length and full tree biomass harvest communities never differed in any of the three epigaeic groups

439 whereas the most extreme bladed treatment was found to show the greatest differences between

440 communities. This partially confirms the second hypothesis in that the increased level of disturbance

441 associated with blading (all three taxa) and stumping (spiders and rove beetles) did generate significant

442 differences in species composition, however the full-tree did not appear to have additional effects to

443 tree-length. In addition, all three taxa had different communities in the older (92 years) fire origin plots

444 than the younger (51 years) harvest origin plots suggesting that communities had not yet recovered

445 from the original harvest disturbance possibly due to a lower volume of coarse woody debris in the

446 younger harvest origin stand. This was contrary to our third hypothesis that suggested that once the

447 overstory returned (younger harvest origin treatment) the faunal composition would recover. The

448 uniqueness of older fire origin stands was most pronounced in the rove beetle communities where the 449 majority of individuals were found in the older fire origin stands.

4514.2 Clearcutting and fire effects on epigaeic assemblages

The primary split for both ground beetles and spiders in the MRT between the mature (92 years

453 old), young (51 years old) and immediate post-fire treatments as compared to the 4 harvested

454 treatments confirms the first hypothesis of expected differences between harvest and fire impacts. This 
455 is not entirely consistent with evidence in the literature that points to removal of the overstory as a 456 primary driver of epigaeic community response (Buddle et al. 2006, Matveinen-Huju and Koivula 2008, 457 Work et al. 2010, 2014, Paradis and Work 2011, Pinzon et al 2013). In these studies up to thirty-five 458 percent of the variance was explained by overstory removal with large increases in open-habitat species 459 (Work et al. 2014). Plots in the post-fire treatment here had limited overstory (live, functioning green 460 canopy) as did harvested plots, whereas mature and young control plots had a closed canopy. Post-fire 461 plots did have 1467 standing dead stems/ha which may have offered some protection, however an 462 examination of the microclimate which is expected to be influenced primarily by overstory, indicates 463 that post-fire plots are more similar to harvested plots with no overstory than to control plots with 464 closed live tree canopies suggesting that microclimate (and overstory) does not explain this first split. One argument that may explain the first split is the forest floor disturbance gradient. Several 466 studies have demonstrated the impact of forest floor disturbance on epigaeic community change but 467 many are confounded with other aspects of forest management (Huhta 1971, Buddle et al. 2000). Siira468 Pietikäinen et al. (2003) examined a series of forest management treatments followed in some cases by 469 harrowing (similar to disc trenching). In their study, gap-felling followed by harrowing reduced the 470 number of soil macroarthropod predators, whereas gap felling without harrowing had no effects on

471 predators, suggesting that harrowing had an impact on community response. Klimaszewski et al. (2005)

472 also showed some limited evidence for an effect of site preparation (in the form of exposing mineral soil 473 by lightly raking a backhoe bucket across the forest organic layer) on carabid beetle communities, with 474 improved habitat for open habitat species (Klimaszewski et al. 2005). This form of site preparation is less 475 intense than disc trenching and may therefore have less impact.

476 In our study, the old control treatment, young control treatment and the recent fire treatment 477 all had the least amount of mineral soil exposure relative to the 4 harvested treatments. This is a good 478 fit with the first split of the MRT for carabids and spiders. In fact, the mineral soil exposure provides a 
good estimate of a general disturbance intensity measure, with treatments ranging from least disturbed to most disturbed; old control, young control, recent fire, tree-length, full -tree biomass, stumped and bladed. In our recent fire treatment, the fire did not expose much of the mineral layer and this would definitely be the low end of the forest floor disturbance gradient for post-fire sites. The evidence from this first split (second split for staphylinidae) is that none of the harvest options that we conducted are a good emulation for our post-fire site. Fire intensity can be highly variable with evidence of large variations in soil burn severity measured as soil organic layer consumption, degree of mineral soil exposure and mean duff layer thickness (Johnstone and Kasischke 2005), so it would be unfair to generalize entirely from our limited sample. There is a need to better understand the variation in fire severity at local, landscape and regional scales in terms of forest floor disturbance since it is an important factor in epigaeic biodiversity (Holliday 1992, Niemela 1999) and critical to emulating natural disturbance (Nguyen-Xuan et al. 2000 Johnstone and Kasischke 2005). Furthermore, natural disturbance emulation needs to consider more than tree species composition and spatial pattern to capture a full range of biodiversity responses. Forest fires often expose mineral soil but they do not achieve the kind of soil disturbance associated with mechanical site preparation (disc trenching), stumping, or blading. Other researchers have come to similar conclusions about the importance of forest floor disturbance but from a different perspective. It has been noted in the literature that ground arthropod succession following wildfires may be delayed relative to harvest due to the generally harsher impact of fire on forest floors than harvest (Holliday 1992, Niemela 1999, Buddle et al. 2006). In our case, the fire was a gentler disturbance than harvest and disc trenching and this resulted in the ground arthropod community in post-fire sites being more similar to the reference conditions than post-harvest sites. Either way, the impact of fire on the forest floor should be measured and emulated to achieve sustainability and forest integrity (Angelstam 1997). 
We also examined the amount of coarse woody debris as influencing community patterns.

503 There is some evidence in the literature of species composition change due to effects of coarse woody 504 debris on microclimate or as protection from predators (Pearce et al. 2003). Community composition in 505 spiders (Castro and Wise 2009, 2010), carabid beetles (Ulyshen and Hanula 2009, Work et al., 2013, 506 2014) and staphylinidae (Work et al 2013) have been linked experimentally to changes in abundance of 507 deadwood. However it has also been suggested that deadwood may only become critical habitat for 508 spiders and ground beetles after overstory removal (Work et al 2014, Pearce et al 2003) where downed 509 deadwood buffers ground beetles from the increased temperature and reduced humidity that 510 accompanies the removal of the overstory. An examination of the pattern of downed coarse wood in 511 the different treatments, however suggests that this factor is not driving the first split since down coarse 512 woody debris is most abundant in the oldest control, the post-fire treatment and the tree-length 513 treatment, and notably very low in the young control, full-tree biomass, stumped and bladed harvest 514 treatments. To explore the second hypothesis that increasing levels of removal of residual biomass will

518 further exacerbate differences in species composition through the compounded effects of loss of coarse 519 wood and increasing soil disturbances, we examined the harvest side of the MRTs. In support of the 520 second hypothesis, the communities in bladed plots were different from all other harvest treatments.

521 This result could be a function of very high forest floor disturbance associated with bladed plots relative 522 to other harvest plots or a function of no coarse wood on bladed plots (Figure 3-54). We are not able to 523 separate the effects of these two potential factors with our data. Spiders and rove beetles do differ 524 somewhat from ground beetles in that carabid beetle communities differ between stumped plots and 525 the other harvested plots, whereas spider and rove beetle communities do not. This may be a function 
526

527

528

530

531

532

533

534

535

536

537

538

539

540

541

542

543

544

545

546

547

548

549

of carabid beetles having part of their life cycle under the soil surface (Lövei and Sunderland 1996),

which is disturbed by the stumping process. Alternatively, carabid beetles could also just be more sensitive to the additional forest floor disturbance associated with stumping..

None of the communities in the three taxa examined differed between full-tree biomass and

tree-length harvesting, suggesting that the intensification of removal associated with biomass harvesting for bioenergy does not cause a significant shift in epigaeic communities, at least in the short-term. This is an important result because full-treebiomass harvesting practices have been criticized as being too intense for the maintenance of sustainability. It remains to be seen if there are longer-term implications of this type of harvesting to epigaeic communities. In particular, there is a concern over changes in the long-term availability of deadwood that may be associated with more intense biomass removal (Berch et al. 2011). In response to this concern in Ontario, the most recent forest management guidelines (OMNR 2010) require the retention of 25 wildlife tree stems per ha. A wildlife tree can include standing healthy, dead or dying trees but is most often living. Ten of these stems must be large. In addition, guidelines require that there be 25 ha of residual forest within any 500 ha circle. These requirements were intentionally not met in our experiment but would improve the availability of deadwood over the longterm and could help improve the time required for arthropod and other communities to recover from disturbance.

\subsection{Recovery of stands after harvest}

We examined the third hypothesis by exploring the control side of the MRT which is very similar for both carabid beetles and spiders. As expected, fire communities split first from the two controls probably due to loss of overstory and changes in associated microclimate (generally warmer and drier). but also maybe due to altered soil chemistry from the chemical processes of fire (McRae et al. 2001). We are unable to separate out the effects of these factors with our current data. In all three taxa the 
550 young and old controls show significant differences in community composition. It is significant and

551 contrary to our third hypothesis that all three assemblages of taxa differ between the old and young

552 controls since it is expected that communities in young forest stands will eventually converge with

553 communities in old forest stands. This convergence has not yet happened in our 51 year old controls

554 and an understanding of when and if this will happen is key to predicting long-term impacts of harvest

555 on biodiversity and sustainability (Venier et al. 2014). The split between old and young controls in all

556 groups may be influenced by deadwood volumes which are much higher in the old control than the

557 young control. None of the other measured environmental factors (overstory, microclimate, and forest

558 floor disturbance) strongly differ between these two treatments. It is possible that community

559 convergence in successional forest stands may therefore be predicted based on accumulated

560 deadwood, an idea that could be tested in a chronosequence experiment. The pattern that rove

561 beetles exhibited using MRT analysis is largely similar to both the spiders and ground beetles in terms of

562 the conclusions we have drawn about our hypotheses, however, most of the rove beetle species were

563 associated with the old control treatment and resulted in an initial split of the old control from all other

564 treatments. The remaining MRT is similar in that the fire and young control communities differ from the

565 harvest stands, the bladed harvest community differs from the other harvest treatment communities,

566 and the stumped, tree-length, and full-tree communities do not split. These results have three

567 implications. First, this suggests that rove beetle communities support the broad conclusions of the

568 other groups. Second, this group could be a very useful indicator of old forest condition, since several

569 species are strongly associated with the old forest control. This is consistent with results from Buddle et

570 al. (2006) which show that rove beetles recover more slowly after harvest disturbance than the other

571 groups. Third, this species group is probably a less useful indicator of alternative harvest or other

572 disturbance treatments than carabid beetles and spiders (Pearce and Venier 2006) due to lower species

573 abundances and fewer species in disturbed plots. Response to loss of old forest and coarse woody 
574 debris may be due to the fungivorous nature of many rove beetles and the associated lower levels of

575 wood decay fungi at lower deadwood levels (Stephani et al. 2016). An alternative explanation for the

576 lack of convergence in the young control plots is the potential isolation of the young controls from older

577 forests that could provide immigration of older-forest specialists. Mature jack pine forests are not

578 common in a $50 \mathrm{~km}$ radius of the young controls and so insufficient dispersal of rove beetles may limit

579 their ability to recover.

A caveat to all of our conclusions related to the control sites is that although we have

581 demonstrated strong similarity in the tree species composition and soil characteristics of all of our sites,

582 the control sites still exist as single sites separated by 10 s of kilometers and so the potential for a

583 geographic effect is present. We believe that the most parsimonious explanations for differences

584 between controls are related to the large treatment effects related to stand origin and time since

585 disturbance but we cannot statistically eliminate geographic effects. This is not an issue for the harvest

586 treatments which are laid out in a randomized block design.

4.5 Species-specific responses

In terms of species-specific responses, only a few carabid species showed a strong affinity for

the control treatments and included Sphaeroderus stenostomus, Scaphinotus bilobus, and Agonum

591 retractum, all species known for their association with closed forest conditions (Buddle et al. 2006).

592 These species showed an affinity for old and young controls over the recent fire. Only a few species

593 showed an affinity for the old control over the young control (Harpalus fuliginosus, Sphaeroderus

594 stenostomus, Synuchus impunctatus), but these species were still often found in the young control.

595 Differences between young and old controls are an indication of lack of convergence, i.e. it is expected

596 that communities in young forests will converge over time to become more similar to communities in

597 old forests. The lack of complete convergence (the difference between communities in young and old 
598

599

600

601

602

603

604

605

606

607

608

609

610

611

612

613

614

615

616

617

618

619

620

controls) for beetles seems to be as much about species with affinity for young forests (i.e. Myas

coracinus) as it is about old forest specialists being restricted to the old control. No spider species showed a strong affinity for old controls over young controls; suggesting that for spiders there is not much concern over habitat supply for old forest specialists. Rove beetles tell a different story. Individual responses of roves beetles indicates that there are many old forest specialists such as Atheta capsularis, A. stigosula, and Oxypoda grandipennis that are found in only very small numbers or not at all in harvested, fire disturbed, or young controls.

We have focused this study on three taxa of epigaeic fauna that have been demonstrated to act as good indicators of environmental change (Pearce and Venier 2006, Work et al. 2008, Klimaszewski et al. 2017 ), but we have not specifically examined saproxylic fauna that are directly dependant on the deadwood resource. Response of saproxylics is expected to be more directly related to quantity of deadwood, and deadwood volumes may provide a good surrogate for saproxylic abundance. Saproxylic sustainability may need to be managed at a landscape rather than stand scale.

\section{Conclusions}

Although the inference space is limited, we found that epigaeic communities differed between fire and harvest disturbance immediately post-disturbance. An examination of environmental factors suggests that an important driver of this difference could be related to forest floor disturbance or mineral soil exposure but is unlikely to be due to differences in microclimate. In our study, site preparation caused significant forest floor disturbance unlike our fire treatment that had low levels of mineral soil exposure. This draws attention to the need to include forest floor disturbance in any consideration of natural disturbance emulation and suggests that we need good understanding about the range of forest floor disturbance precipitated by fire through the natural range of fire intensity. 
Within our harvest treatments, the bladed treatment was found to show the greatest

622 differences between communities of all three taxonomic groups whereas tree-length and full-tree

623 biomass harvest communities never differed in any of the three epigaeic groups. This suggests that

624 blading is a practice that is unlikely to be sustainable from an epigaeic community perspective and

625 although it is not a current practice it may reflect longer term impacts of repeated deadwood removal. It

626 clearly demonstrates that there is a point at which forest disturbance will undermine biotic

627 communities. The lack of difference between communities within full-tree biomass and tree-length

628 suggests that increased removals associated with full-tree biomass harvest beyond the tree-length

629 alternative that has been promoted as more sustainable do not appear to be compromising the short-

630 term epigaeic biodiversity. Lack of a short-term effect however, does not preclude a longer-term impact

631 associated with loss of deadwood availability over time.

632 The epigaeic communities did differ between old (post-fire) controls (92 years) and young post-

633 harvest controls (51 years), most strongly for rove beetles but also for ground beetles and spiders. The

634 most obvious environmental difference between old and young controls was the amount of deadwood

635 available and may have accounted for community differences. Mature forest communities of ground

636 beetles and spiders are not composed of many unique old-growth species but do have compositions

637 that are distinguishable from younger closed canopy forest. Mature forest rove beetle communities are

638 much more unique and contain many species that are very poorly represented in any of the other

639 treatments, suggesting that old forest conditions are a more necessary element in the landscape for 640 rove beetles.

641

642 6. Acknowledgements 
645 Kerrie Wainio-Keizer, Kevin Good, Stephanie Dumas all supported field data collection. Tom Weldon, 646 Mark Primavera, Stephanie Wilson and Gord Brand provided logistic support for field work, data 647 management and figure production. Emilie Rivest identified the ground beetles. Funding was provided 648 through an NSERC Collaborative Research Agreement to Christian Messier and through an EcoEnergy 649 Innovation Initiative Grant, NRCan to Lisa Venier.

650

7. Literature Cited

652

Angelstam, P. 1997. Landscape analysis as a tool for the scientific management of biodiversity. Ecol. Bull. 46: $140-170$.

655 656

Ashe, J.S. 2001. Key to the tribes and genera of Nearctic Aleocharinae. 8. In: American Beetles. Archostemata, Myxophaga, Adephaga, Polyphaga: Staphyliniformia. Edited by R.H. Arnett, Jr, and C.M. Thomas. CRC Press, Boca Raton, London, New York, Washington, D.C. pp. 299-374.

Bates, D., Maechler, M., Bolker, B., and Walker, S. 2015. Fitting Linear Mixed-Effects Models Using Ime4. Journal of Statistical Software, 67(1), 1-48. doi:10.18637/jss.v067.i01.

Berch, S.M., Morris, D. and Malcolm, J. 2011. Intensive forest biomass harvesting and biodiversity in Canada: A summary of relevant issues. For. Chron. 87 (4): 478-487.

Bergeron, Y., Gauthier, S., Kafka, V. Lefort, P. and Lesieur.D. 2001. Natural fire frequency for the eastern Canadian boreal forest: consequences for sustainable forestry. Can. J. For. Res. 31(3): 384-391. doi: 10.1139/x00-178.

Bergeron, Y., Leduc, A., Harvey, B.D., Gauthier, S. 2002. Natural fire regime: a guide for sustainable management of the Canadian boreal forest. Silva Fennica 36: 81-95. 
Björheden, R. 2006. Drivers behind the development of forest energy in Sweden. Biomass Bioenergy 30: 289-295.

Bousquet, A., Larochelle Y. 1993. Catalogue of the Geadephaga (Coleoptera: Trachypachidae, Rhysodidae, Carabidae including Cicindelini) of America north of Mexico. Mem. Entomol. Soc. Can. 167:397.

Brais, S., Sadi,F., Bergeron, Y., and Grenier, Y. 2005. Coarse woody debris dynamics in a post-fire jackpine chronosequence and its relation with site productivity. For. Ecol. Manage. 220:216-226.

Brunke, A., Newton, A., Klimaszewski, J., Majka, C. and Marshall, S. 2011. Staphylinidae of Eastern Canada and Adjacent United States. Key to Subfamilies; Staphylininae: Tribes and Subtribes, and Species of Staphylinina. Canadian Journal of Arthropod Identification No. 12, 20 January 2011, Available from http://www.biology.ualberta.ca/bsc/ejournal/bnkmm 12/index.html. doi: 10.3752/cjai.2011.12.

Buddle, C.M., Spence, J.R., and Langor, D.W. 2000. Succession of boreal forest spider assemblages following wildfire and harvesting. Ecography 23: 424-436.

Buddle, C.M., Langor, D.W., Pohl, G.R., and Spence, J.R. 2006. Arthropod responses to harvesting and wildfire: Implications for emulation of natural disturbance in forest management. Biological Conservation 128: 346-357.

Castro, A. and Wise, D.H. 2009. Influence of fine woody debris on spider diversity and community structure in forest leaf litter. Biodiversity and Conservation 18:3705-3731.

Castro, A. and Wise, D.H. 2010. Influence of fallen coarse woody debris on the diversity and community structure of forest-floor spiders (Arachnida: Araneae). For. Ecol. Manage. 260: 2088-2101.

Chaundy-Smart, R. F. C., Smith,S.M., Malcolm, J.R. and Bellocq, M.I. 2012. Comparison of moth communities following clear-cutting and wildfire disturbance in the southern boreal forest. For. Ecol. Manage. 270:273-281. 
691 De'ath, G. 2011 mvpart: Multivariate partitioning. R package version 1.4-0. http://CRAN.R-

692 project.org/package=mvpart.

693 De'ath, G. 2002. Multivariate regression trees: a new technique for modeling species-environment relationships. Ecology 83:1105-1117.

Environment Canada. 2013. National Climate Data and Information Archive. Available from http://www.climate.weatheroffice.gc.ca/Welcome e.htm [accessed 26 June 2013].

697

698

699

700

701

702

703

704

705

706

707

708

709

710

711

712

713

714

Gauthier, S., Gagnon, J., and Bergeron, Y. 1993. Jack pine (Pinus banksiana Lamb.) population age structure: effects of forest age, site types and fire regimes. Journal of Vegetation Science 4:783790.

Gauthier, S., Vaillancourt, M.-A., Leduc, A., De Grandpré, L., Kneeshaw, D., Morin, H., Drapeau, P., Bergeron, Y. 2009. Ecosystem Management in the Boreal Forest. Presses de l'Université du Québec, Québec.

Graham-Sauvé, L., Work, T.T., Kneeshaw, D. and Messier, C. 2013. Shelterwood and multicohort management have similar initial effects on ground beetle assemblages in boreal forests. For. Ecol. Manage. 306:266-274.

Greene, D. F., Noël, J. Bergeron, Y. Rousseau, M. and Gautier, S. 2004. Recruitment of Picea mariana, Pinus banksiana, and Populus tremuloides across a burn severity gradient following wildfire in the southern boreal forest of Quebec. Can. J. For. Res. 34:1845-1857.

Hakkila, P. 2004. Puuenergian teknologiaohjelma 1999-2003 (Wood energy technology programme 1999-2003). Loppuraportti. Teknologiaohjelmaraportti 5/2004, 135 pp. (In Finnish).

Holliday, N.J. 1992. The carabid fauna (Coleoptera: Carabidae) during post-fire regeneration of boreal forests: properties and dynamics of species assemblages. Can. J. Zool. 70: 440-452.

Hothorn, T., Bretz, F., and Westfall, P. 2008. Simultaneous Inference in General Parametric Models. Biometrical Journal 50(3), 346--363. 
Huhta, V. 1971. Succession in the spider communities of the forest floor after clear-cutting and prescribed burning. Ann. Zool. Fenn. 8:483-542.

Hunter, M.L. 1993. Natural fires regimes as spatial models for managing boreal forests. Biological Conservation 65:115-120.

Johnstone, J.F. and Kasischke, E.S. 2005. Stand-level effects of soil burn severity on postfire regeneration in a recently burned black spruce forest. Can. J. For. Res. 35: 2151-2163.

Klimaszewski, J., Brunke, A., Work, T., Venier, L. 2017 in press. Chapter 2.2. Rove beetles (Coleoptera, Staphylinidae) as bioindicators of change in boreal forests and their biological control services in agroecosystems: Canadian case studies. In Biology of Rove Beetles (Staphylinidae) - Life History, Evolution, Ecology and Distribution, Edited by Oliver Betz, Ulrich Irmler and Jan Klimaszewski. Springer.

Klimaszewski, J., Langor, D.W., Work,T.T., Pelletier,G., Hammond, H.E.J. and Germaine, C. 2005. The effects of patch harvesting and site preparation on ground beetles (Coleoptera, Carabidae) in yellow birch dominated forests of southeastern Quebec. Can. J. For. Res. 35:2616-2628.

Koivula, M., and Spence, J.R. 2006. Effects of post-fire salvage logging on boreal mixed-wood ground beetle assemblages (Coleoptera, Carabidae). For. Ecol. Manage. 236:102-112.

Kwiaton, M., Hazlett, P., Morris, D., Fleming, R., Webster, K., Venier, I., Aubin, I. 2014. Island Lake Biomass Harvest Research and Demonstration Area: Establishment Report. Natural Resources Canada, Canadian Forest Service, Great Lakes Forestry Centre, Information Report GLC - X - 11.

Lindroth CH (1961-1969) The ground-beetles (Carabidae, excl Cicindelinae) of Canada and Alaska. (Suppl. 20 (1961), 24 (1963), 29 (1966), 33 (1969), \& 35 (1969). Opuscula Entomologica, Lund University, Sweden.

Long, J.N. 2009. Emulating natural disturbance regimes as a basis for forest management: A North American view. For. Ecol. Manage. 257: 1868-1873. 
739 740

741

742

743

744

745

746

747

748

749

750

751

752

753

754

755

756

757

758

759

760

761

Lovei, G.L. and Sunderland, K.D. 1996. Ecology and behavior of ground beetles (Coleoptera: Carabidae). Annu. Rev. Entomol.41:231-256. doi: 10.1146/annurev.en.41.010196.001311

Marshall, P.L., Davis, G., LeMay, V.M. 2000. Using line intersect sampling for coarse woody debris. Technical Report TR-003. Nanaimo (BC): Vancouver Forest Region, British Columbia Ministry of Forests. Available from http://www.for.gov.bc.ca/rco/research/cwd/tr003.pdf

Martikainen, P., Kouki, J. and Heikkala, O. 2006. The effects of green tree retention and subsequent prescribed burning on ground beetles (Coleoptera: Carabidae) in boreal pine-dominated forests. Ecography 29:659-670.

Matveinen-Huju, K., and Koivula, M. 2008. Effects of alternative harvesting methods on boreal forest spider assemblages. Can. J. For. Res. 38: 782-794. doi:10.1139/X07-169.

McRae, D.J., Duchesne, L.C., Freedman, B., Lynham, T.J., and Woodley, S. 2001. Comparisons between wildfire and forest harvesting and their implications in forest management. Environ. Rev.9:223260.

Munson, A.D., Margolis, H.A., Brand, D.G., 1993. Intensive silvicultural treatment: Impacts on soil fertility and planted conifer response. Soil Sci. Soc. Am. J. 57: 246-255.

Munson, A.D., Timmer, V.R., 1995. Soil nitrogen dynamics andnutrition of pine following silvicultural treatments in boreal and Great lakes \pm St. Lawrence plantations. For. Ecol. Manage. 76:169179.

Naesset, E. 1999. Relationship between relative wood density of Picea abies logs and simple classification systems of decayed coarse woody debris. Scandinavian Journal of Forest Research $14: 454-461$.

Niemelä, J. 1999. Management in relation to disturbance in the boreal forest. For. Ecol. Manage. 115:127-134. 
762 763

764

765

766

767

768

769

770

771

772

773

774

775

776

777

778

779

780

781

782

783

784

Niemelä, J., Langor, D. and Spence, J.R. 1993. Effects of clear-cut harvesting on boreal ground-beetle assemblages (Coleoptera: Carabidae) in Western Canada. Conservation Biology 7:551-561.

Nguyen-Xuan, T., Bergeron, Y., Simard, D., Fyles, j.W., Paré, D. 2000. The importance of forest floor disturbance in the early regeneration patterns of the boreal forest of western and central Quebec : a wildfire versus logging comparison. Can. J. For. Res. 30: 1353-1364.

OMNR 1997. Silvicultural guide to managing for black spruce, jack pine, and aspen on boreal forest ecosites in Ontario. Version 1.1. Ontario Ministry of Natural Resources. Queen's Printer for Ontario, Toronto. 3 books. 822pp.

OMNR 2010. Forest Management Guide for Conserving Biodiversity at the Stand and Site Scales. Toronto: Queen's Printer for Ontario. 211pp.

OMNR 2013. Emulating natural disturbances : clearcut silviculture in Ontario. State of Resources Reporting. Ontario Ministry of Natural Resources. Available from https://dr6j45jk9xcmk.cloudfront.net/documents/3123/stdprod-110056.pdf

Paquin P and Duperre N. 2003. Guide d'identification des araignees (Araneae) du Quebec. Varieties, Quebec: Association des entomologistes amateurs du Quebec.

Paradis, S. and Work, T.T. 2011. Partial cutting does not maintain spider assemblages within the observed range of natural variability in Eastern Canadian black spruce forests. For. Ecol. Manage. 262: 2079-2093.

Pearce, J.L., Venier,L.A., McKee,J., Pedlar, J., McKenney, D. 2003. Influence of habitat and microhabitat on carabid (Coleoptera: Carabidae) assemblages in four stand types. The Canadian Entomologist 135: 337-357.

Pearce, J.L. and Venier, L.A. 2006. The use of ground beetles (Coleoptera: Carabidae) and spiders (Araneae) as bioindicators of sustainable forest management: A review. Ecol. Indic. 6: 780-793. 
785 786 787 788 789 790

791 792 793 794 795 796 797 798 799 800 801 802 803 804 805 806 807 808

Pinzon, J., Spence, J.R. and Langor, D.W. 2013. Effects of prescribed burning and harvesting on ground dwelling spiders in the Canadian boreal mixedwood forest. Biodiversity and Conservation 22:1513-1536.

Pohl, G. R., Langor, D. and Spence, J.R. 2007. Rove beetles and ground beetles (Coleoptera: Staphylinidae, Carabidae) as indicators of harvest and regeneration practices in western Canadian foothills forests. Biological Conservation 137:294-307.

R Development Core Team (2011). R: A language and environment for statistical computing. R Foundation for Statistical Computing, Vienna, Austria. Available from https://www.Rproject.org/.

Reich, P. B., P. Bakken, P. Carlson, D.,Frelich,L.E., Friedman, S.K., and Grigal, D.F. 2001. Influence of logging, fire, and forest type on biodiversity and productivity in southern boreal forests. Ecology 82:2731-2748.

Ryans, M. and Sutherland, B. 2001. Site preparation-mechanical. In R.G. Wagner and S.J. Colombo, eds., Regenerating the Canadian Forest: Principles and Practice for Ontario. Ontario Ministry of Natural Resources, Fitzhenry \& Whiteside Limited, Markham, Ontario, Canada.

Seevers, C.H. 1978. A generic and tribal revision of the North American Aleocharinae (Coleoptera: Staphylinidae). Fieldiana Zoology 71: 289 pp.

Siira-Pietikainen, A., J.Haimi, and J. Siitonen. 2003. Short-term responses of soil macroarthropod community to clear felling and alternative forest regeneration methods. For. Ecol. Manage. 172: 339-353.

Stephani, F.O.P., Klimaszewski, J., Morency, M.-J., Bourdon, C., Labrie, P., Blais, M., Venier, L. and Seguin, A. 2016. Fungal community composition in the gut of rove beetles (Coleoptera: Staphylinidae) from the Canadian boreal forest reveals possible endosymbiotic interactions for dietary needs. Fungal Ecology 23: 164-171. 
Suffling, R, Smith, B., Dal Molin, J. 1982. Estimating past forest age distributions and disturbance rates in north-western Ontario: A demographic approach. Journal of Environmental Management 14:4556

Thiffault, E., Bechard, A., Pare, D., \& Allen, D. 2014. Recovery Rate of harvest residues for bioenergy in boreal and temperate forests: A Review. WIREs Energy and Environment, 4(5). Retrieved from http://onlinelibrary.wiley.com/doi/10.1002/wene.157/abstract;jsessionid=844E315A775517D1 AA9F125081F03076.f01t04?userlsAuthenticated=false\&deniedAccessCustomisedMessage=

Thiffault, E., Hannam, K. D., Paré, D., Titus, B. D., Hazlett, P. W., Maynard, D. G., \& Brais, S. 2011. Effects of forest biomass harvesting on soil productivity in boreal and temperate forests - A review. Environmental Reviews, 19, 278-309. Retrieved from http://www.nrcresearchpress.com/action/showCitFormats?doi=10.1139\%2Fa11-009

Ulyshen, M.D. and J.L. Hanula. 2009. Responses of arthropods to large-scale manipulations of deadwood in loblolly pine stands in the southeastern United States. Environmental Entomology 38: 10051012

Venier, L.A., Thompson, I.D., Fleming,R., Malcolm,J., Aubin,I., Trofymow, J.A., Langor, D., Sturrock,R., Patry, C., Outerbridge, R.O., Holmes, S.B., Haeussler, S., De Grandpré,L., Chen, H.Y.H., Bayne, E., Arsenault,A. and Brandt, J.P. 2014. Effects of natural resource development on the terrestrial biodiversity of Canadian boreal forests. Environmental Reviews 22: 457-490. Dx.doi.org/10.1139/er-2013-0075.

Weber, M. G., M. Hummel, and C. E. Van Wagner. 1987. Selected parameters of fire behavior and Pinus bankisana Lamb. regeneration in Eastern Ontario. Forestry Chonicle 63:340-346.

Work, T.T., Brais, S., and Harvey, B.D. 2014. Reductions in downed deadwood from biomass harvesting alter composition of spiders and ground beetle assemblages in jack-pine forests of Western Quebec. For. Ecol. Manage. 321:19-28. 
833 Work, T.T., Jacobs, J.M., Spence, J.R. and Volney, W.J. 2010. High levels of green-tree retention are 834 required to preserve ground beetle biodiversity in boreal mixedwood forests. Ecological 835 Applications 20: 741-751.

836 Work, T.T., Klimaszewski, J., Thiffault, E., Bourdon, C., Pare, D., Bosquet, Y., Venier, L.A., Titus, B.D. 2013. 837 Initial responses of rove and ground beetles (Coleoptera, Staphylinidae, Carabidae) to removal 838 of logging residues following clearcut harvesting in the boreal forest of Quebec, Canada. Zookeys 258: 31-52.

840 Work, T.T., Koivula, M., Klimaszewski, J., Langor, D., Spence, J., Sweeney, J. and Hebert, C. 2008. Evaluation of carabid beetles as indicators of forest change in Canada. Can. Entomol 140: 393414.

843 World Spider Catalog. 2017. World Spider Catalog. Natural History Museum Bern online at 844 http://wsc.nmbe.ch, version 18.0 
Table 1: Stand characteristics for the three reference condition stands. The Recent Fire is a recently burned stand and therefore has no standing live volume. Pre-treatment measures that are relevant to justify stand similarity are highlighted in grey. The other measures are different due to treatment effects.

\begin{tabular}{|c|c|c|c|}
\hline & Island Lake & Recent Fire & Old Control \\
\hline Stand Age at time of epigaeic sampling(yrs) & 51 & $3 *$ & 92 \\
\hline Species Composition (\%) & $\mathrm{Pj}_{99} \mathrm{Sb}_{1}$ & $\mathrm{Pj}_{100}$ & $\mathrm{Pj}_{90} \mathrm{Sb}_{10}$ \\
\hline Tree Density (stems per hectare) & 2005 & $1467^{* *}$ & $1870 * * *$ \\
\hline Gross Total Volume $\left(\mathrm{m}^{3} \mathrm{ha}^{-1}\right)$ & 189.6 & $107.4^{* *}$ & 289.5 \\
\hline Site Index ( $m$ @ BHA $A_{50}$ ) & 19.3 & $19.5^{* *}$ & 18.8 \\
\hline Standing Dead Volume $\left(\mathrm{m}^{3} \mathrm{ha}^{-1}\right)$ & 9.66 & 107.41 & 37.92 \\
\hline DWD Aboveground Fine Volume $\left(\mathrm{m}^{3} \mathrm{ha}^{-1}\right)$ & 1.39 & 2.81 & 0.58 \\
\hline \multirow[t]{2}{*}{ DWD Aboveground Coarse Volume $\left(\mathrm{m}^{3} \mathrm{ha}^{-1}\right)$} & 11.03 & 41.56 & 75.98 \\
\hline & \multicolumn{3}{|c|}{ \% Proportion DWD Aboveground Coarse Volume by Decay } \\
\hline DC 1 & 8 & 4 & 17 \\
\hline DC 2 & 23 & 13 & 22 \\
\hline DC 3 & 11 & 27 & 19 \\
\hline DC 4 & 9 & 36 & 33 \\
\hline DC 5 & 48 & 21 & 8 \\
\hline DWD Belowground Coarse Volume $\left(\mathrm{m}^{3} \mathrm{ha}^{-1}\right)$ & 13.94 & 5.21 & 15.30 \\
\hline Mode of Deposition & GF & GF & GF \\
\hline Profile Development & DYB & DYB & DYB \\
\hline Soil Texture & SiS-mS & LmS-mS & SiL - LmS \\
\hline Coarse Fragment (\%) & 10 & 0 & 20 \\
\hline Forest Humus Form & $\mathrm{F}$ & $\mathrm{FH}$ & $\mathrm{HF}$ \\
\hline Forest Floor Depth (cm) & 10 & 5.4 & 9 \\
\hline Soil Moisture Regime & moderately dry & moderately dry & moderately dry \\
\hline Soil Drainage & rapid & rapid & rapid \\
\hline
\end{tabular}

*Recent Fire was a 30-year-old jack pine plantation when it burned in the spring of 2010

** Data from standing dead inventory measured post-fire

*** Pj density is 778 with $\mathrm{Sb}$ ingress at 1041 stems per hectare

Species Composition: $\mathrm{Pj}=$ Jack Pine, $\mathrm{Sb}=$ Black

Spruce

Mode of Deposition: GF = GlacioFluvial

Profile Development: DYB = Dystric Brunisol

Soil Texture: $\mathrm{LmS}=$ Loamy medium Sand, $\mathrm{mS}$ = medium Sand, SiL = Silty Loam, SiS = Silty Sand 
Forest Humus Form: $\mathrm{F}=$ Fibrimor, $\mathrm{FH}=$ Fibri Humimor, $\mathrm{HF}=\mathrm{Humi}$ Fibrimor 
Table 2: Carabid beetle individual species variances by split within the SSMRT, total tree variance and total variance explained for the multivariate regression tree.

\begin{tabular}{llllllll}
\hline & Split-1 & Split-2 & Split-3 & Split-4 & Split-5 & $\begin{array}{l}\text { Tree } \\
\text { total }\end{array}$ & $\begin{array}{l}\text { Species } \\
\text { total }\end{array}$ \\
\hline Agonum retractum & 0.495 & 0.023 & 0.017 & 0.057 & 0.004 & 0.595 & 1.379 \\
Bembidion nitidum & 0.120 & 0.000 & 0.609 & 0.000 & 0.007 & 0.735 & 0.791 \\
Calathus ingratus & 0.053 & 0.729 & 0.911 & 0.034 & 0.176 & 1.903 & 3.650 \\
Harpalus affinis & 0.126 & 0.000 & 0.649 & 0.000 & 0.007 & 0.782 & 0.835 \\
Harpalus fuliginosus & 0.301 & 0.004 & 0.190 & 0.021 & 0.059 & 0.574 & 1.072 \\
Harpalus laticeps & 1.787 & 0.872 & 0.898 & 0.005 & 0.170 & 3.731 & 4.641 \\
Harpalus pensylvanicus & 0.402 & 0.000 & 0.471 & 0.000 & 0.185 & 1.057 & 1.379 \\
Harpalus plenalis & 2.835 & 0.000 & 0.000 & 0.005 & 0.385 & 3.225 & 5.583 \\
Myas coracinus & 0.052 & 1.306 & 0.394 & 1.047 & 0.076 & 2.874 & 4.159 \\
Poecilius lucublandus & 15.186 & 0.000 & 1.228 & 0.000 & 0.006 & 16.419 & 17.760 \\
Pterostichus adstrictus & 11.907 & 0.584 & 12.102 & 0.233 & 1.007 & 25.832 & 28.272 \\
Pterostichus coracinus & 0.211 & 3.556 & 1.792 & 0.004 & 0.965 & 6.527 & 9.572 \\
Pterostichus pensylvanicus & 0.393 & 1.439 & 1.437 & 0.244 & 0.228 & 3.740 & 5.257 \\
Scaphinotus bilobus & 0.367 & 0.618 & 0.017 & 0.166 & 0.004 & 1.171 & 1.743 \\
Sphaeroderus stenostomus & 1.409 & 1.973 & 0.020 & 0.436 & 0.041 & 3.879 & 4.279 \\
Syntomus americanus & 0.216 & 0.069 & 0.127 & 0.005 & 0.260 & 0.677 & 1.219 \\
Synuchus impunctatus & 0.307 & 0.001 & 1.459 & 0.367 & 0.046 & 2.179 & 2.989 \\
Less Common Species (17) & 0.551 & 0.123 & 0.489 & 0.159 & 0.414 & 1.736 & 5.420 \\
\hline Total & 36.718 & 11.294 & 22.808 & 2.782 & 4.036 & 77.638 & 100.000 \\
\hline
\end{tabular}


Table 3: Spider individual species variances by split within the SSMRT, total tree variance and total variance explained for the multivariate regression tree.

\begin{tabular}{llllllll}
\hline Species & Split-1 & Split-2 & Split-3 & Split-4 & Split-5 & $\begin{array}{l}\text { Tree } \\
\text { Total }\end{array}$ & $\begin{array}{l}\text { Species } \\
\text { Total }\end{array}$ \\
\hline Agroeca ornata & 0.107 & 0.461 & 0.080 & 0.020 & 0.066 & 0.734 & 1.144 \\
Agyneta simplex & 0.063 & 0.443 & 0.008 & 0.004 & 0.006 & 0.525 & 0.962 \\
Alopecosa aculeata & 0.019 & 0.399 & 0.251 & 0.388 & 0.563 & 1.621 & 2.272 \\
Amaurobius borealis & 0.143 & 2.036 & 1.549 & 0.826 & 1.914 & 6.468 & 7.632 \\
Cicurina arcuata & 0.098 & 0.366 & 0.038 & 0.005 & 0.027 & 0.534 & 0.947 \\
Cicurina brevis & 0.170 & 0.654 & 0.001 & 0.023 & 0.001 & 0.849 & 1.469 \\
Cybaeopsis euopla & 0.402 & 0.569 & 0.068 & 0.000 & 0.725 & 1.765 & 2.356 \\
Gnaphosa parvula & 0.521 & 0.000 & 0.000 & 0.000 & 0.000 & 0.521 & 0.905 \\
Hahnia cinerea & 0.000 & 0.082 & 0.274 & 0.137 & 0.331 & 0.824 & 1.732 \\
Haplodrassus signifer & 0.627 & 0.145 & 0.000 & 0.026 & 0.005 & 0.803 & 1.511 \\
Islandiana flaveola & 1.023 & 0.005 & 0.002 & 0.000 & 0.000 & 1.030 & 1.559 \\
Lepthyphantes intricatus & 0.247 & 0.157 & 0.060 & 0.022 & 0.071 & 0.558 & 1.273 \\
Mermessus trilobatus & 0.619 & 0.001 & 0.026 & 0.004 & 0.000 & 0.650 & 1.101 \\
Pardosa distincta & 4.027 & 0.000 & 0.043 & 0.000 & 0.000 & 4.070 & 5.013 \\
Pardosa hyperborea & 0.646 & 0.007 & 0.481 & 3.179 & 0.688 & 5.001 & 7.111 \\
Pardosa moesta & 9.659 & 0.130 & 1.413 & 0.009 & 0.012 & 11.223 & 15.467 \\
Pardosa xerampelina & 8.519 & 1.464 & 1.138 & 0.000 & 0.000 & 11.122 & 13.897 \\
Sciastes truncatus & 0.101 & 1.715 & 0.475 & 0.348 & 0.879 & 3.518 & 4.148 \\
Trochosa terricola & 1.725 & 2.109 & 0.598 & 0.065 & 0.614 & 5.111 & 5.890 \\
Less Common Species (99) & 1.807 & 1.239 & 2.659 & 0.695 & 0.629 & 7.029 & 23.614 \\
\hline Total & 30.523 & 11.982 & 9.164 & 5.755 & 6.532 & 63.956 & 100.000 \\
\hline
\end{tabular}


Table 4: Rove beetle individual species variances by split within the SSMRT, total tree variance and total variance explained for the multivariate regression tree.

\begin{tabular}{lllllll}
\hline & Split-1 & Split-2 & Split-3 & Split-4 & $\begin{array}{l}\text { Tree } \\
\text { Total }\end{array}$ & $\begin{array}{l}\text { Species } \\
\text { Total }\end{array}$ \\
\hline Aleochara fumata & 0.324 & 3.021 & 0.015 & 0.012 & 3.372 & 5.486 \\
Aleochara verna & 0.046 & 0.182 & 0.000 & 0.525 & 0.754 & 1.272 \\
Amischa sp. & 0.014 & 0.054 & 0.000 & 0.459 & 0.527 & 0.694 \\
Atheta capsularis & 13.031 & 0.509 & 0.451 & 0.000 & 13.991 & 14.720 \\
Atheta modesta & 2.779 & 1.005 & 0.330 & 0.000 & 4.114 & 4.622 \\
Atheta remulsa & 4.339 & 0.001 & 0.014 & 0.175 & 4.529 & 6.553 \\
Atheta strigosula & 8.934 & 0.007 & 0.000 & 0.000 & 8.941 & 9.078 \\
Atheta terranovae & 0.860 & 0.000 & 0.083 & 0.000 & 0.943 & 1.196 \\
Heterothops fusculus & 0.124 & 0.331 & 0.000 & 1.193 & 1.648 & 2.458 \\
Lordithon fungicola & 7.926 & 0.007 & 0.003 & 0.037 & 7.973 & 8.843 \\
Megarthrus excisus & 0.329 & 0.000 & 0.205 & 0.000 & 0.535 & 0.614 \\
Mycetoporus consors & 0.700 & 0.323 & 0.001 & 0.256 & 1.280 & 3.033 \\
Oxypoda grandipennis & 6.316 & 0.000 & 0.677 & 0.000 & 6.993 & 7.213 \\
Philonthus caerulipennis & 2.077 & 0.119 & 0.052 & 0.017 & 2.265 & 2.870 \\
Proteinus acadiensis & 1.356 & 0.000 & 0.248 & 0.000 & 1.604 & 2.117 \\
Proteinus pseudothomasi & 0.785 & 0.002 & 0.134 & 0.002 & 0.923 & 1.381 \\
Quedius fulvicollis & 0.755 & 0.000 & 0.001 & 0.000 & 0.756 & 1.102 \\
Silusa californica & 1.458 & 0.026 & 0.152 & 0.000 & 1.636 & 1.848 \\
Tachinus picipes & 1.595 & 0.476 & 0.026 & 0.002 & 2.100 & 4.049 \\
Tachinus quebecensis & 1.682 & 0.038 & 0.002 & 0.000 & 1.723 & 2.100 \\
Less Common Species (50) & 2.297 & 0.844 & 0.979 & 0.797 & 4.917 & 18.752 \\
\hline Total & 57.725 & 6.945 & 3.374 & 3.475 & 71.520 & 100.000 \\
\hline
\end{tabular}




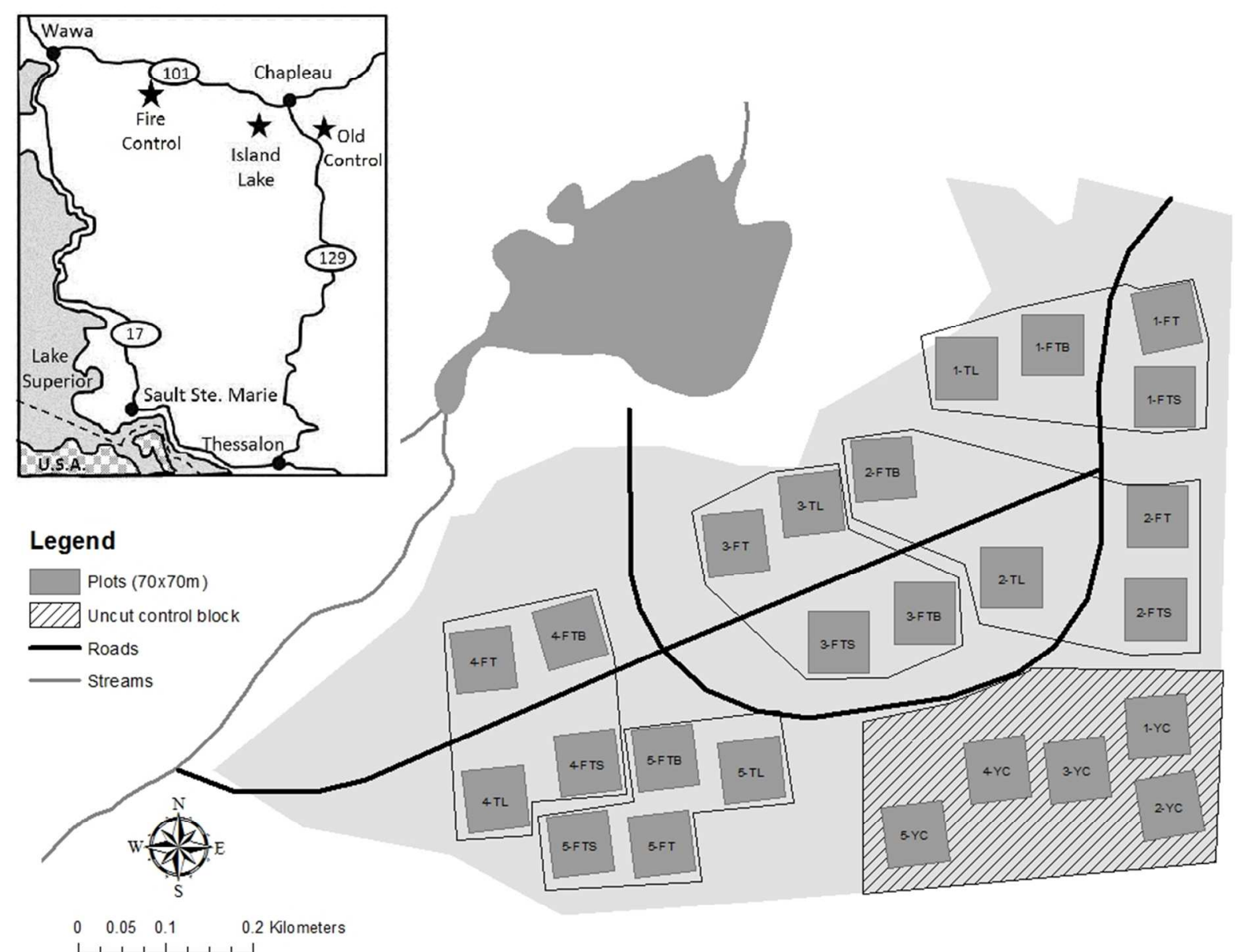


(a)

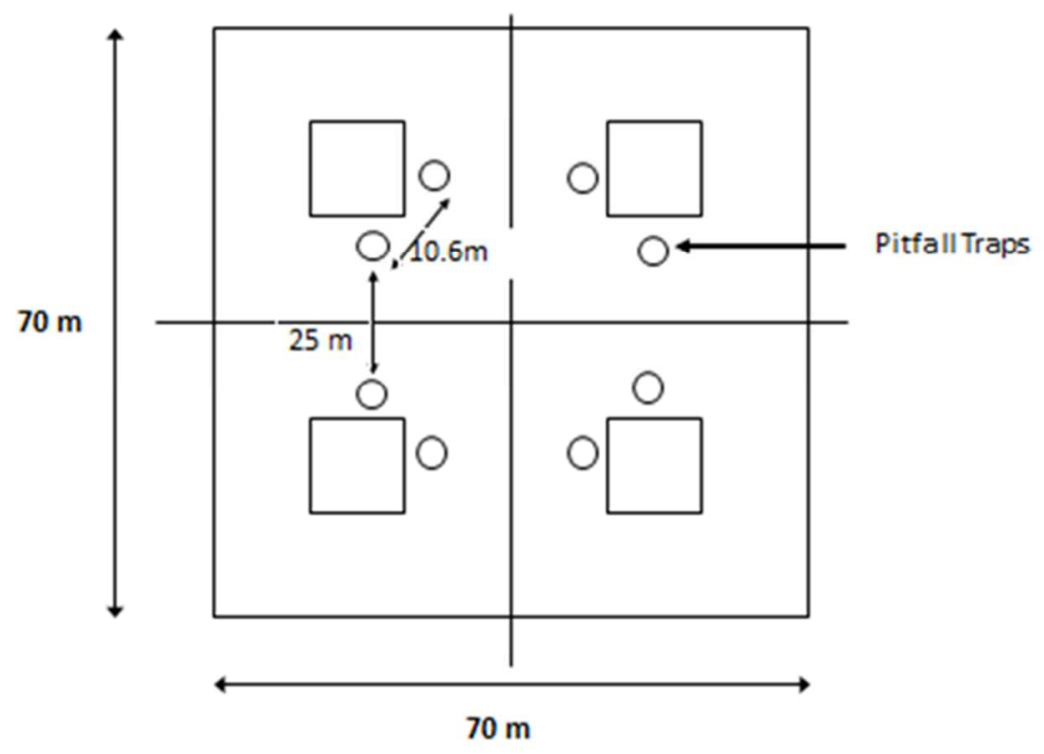


(b)

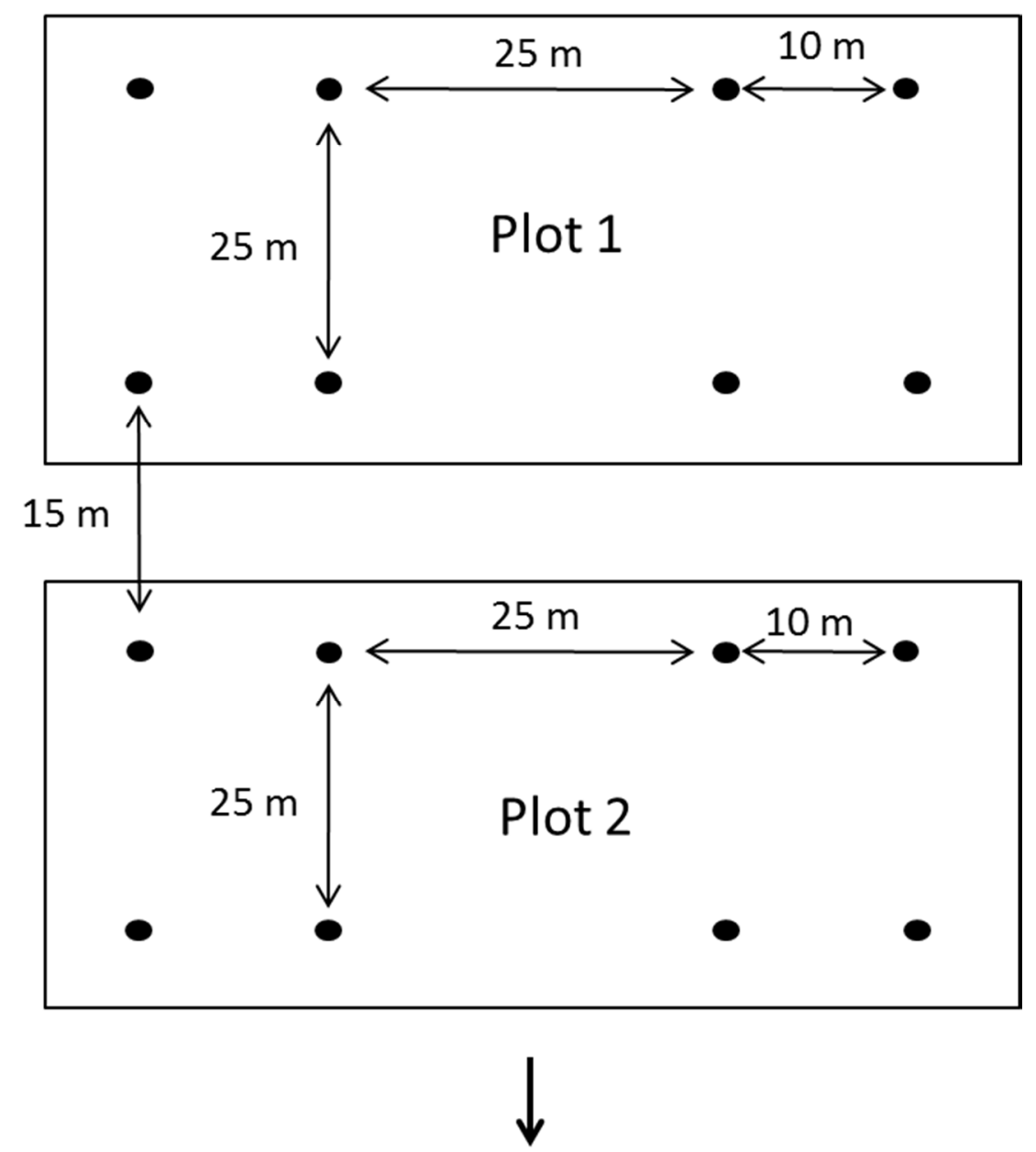

Continued to Plot 6 
Figure 3

(a)

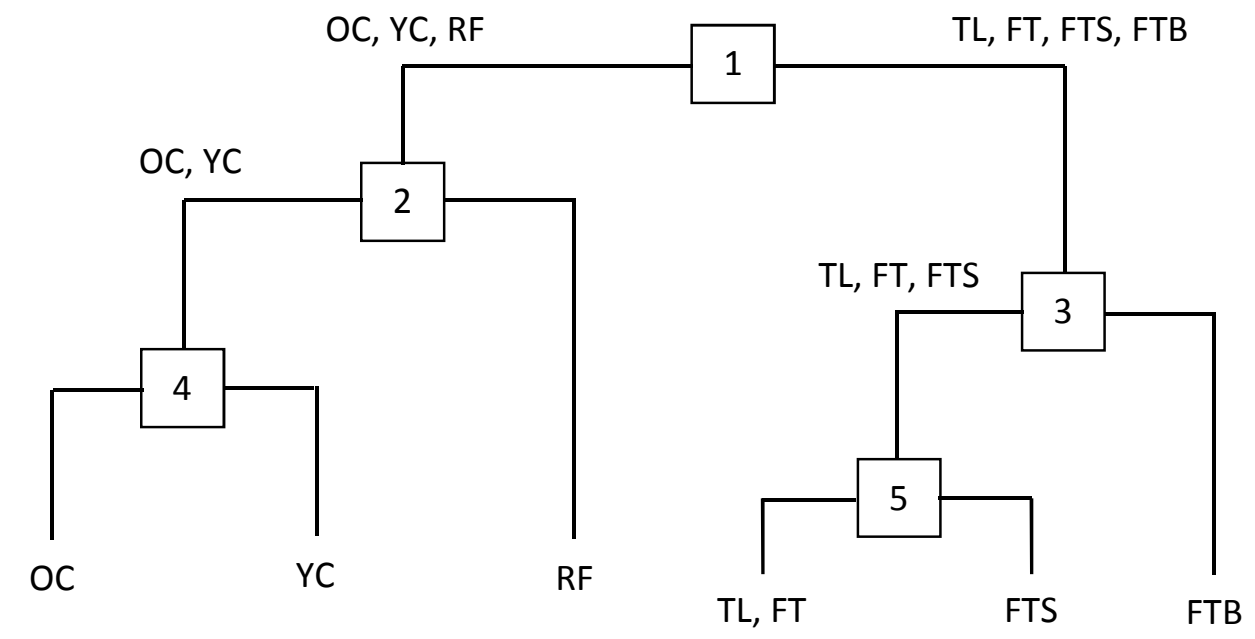


(b)

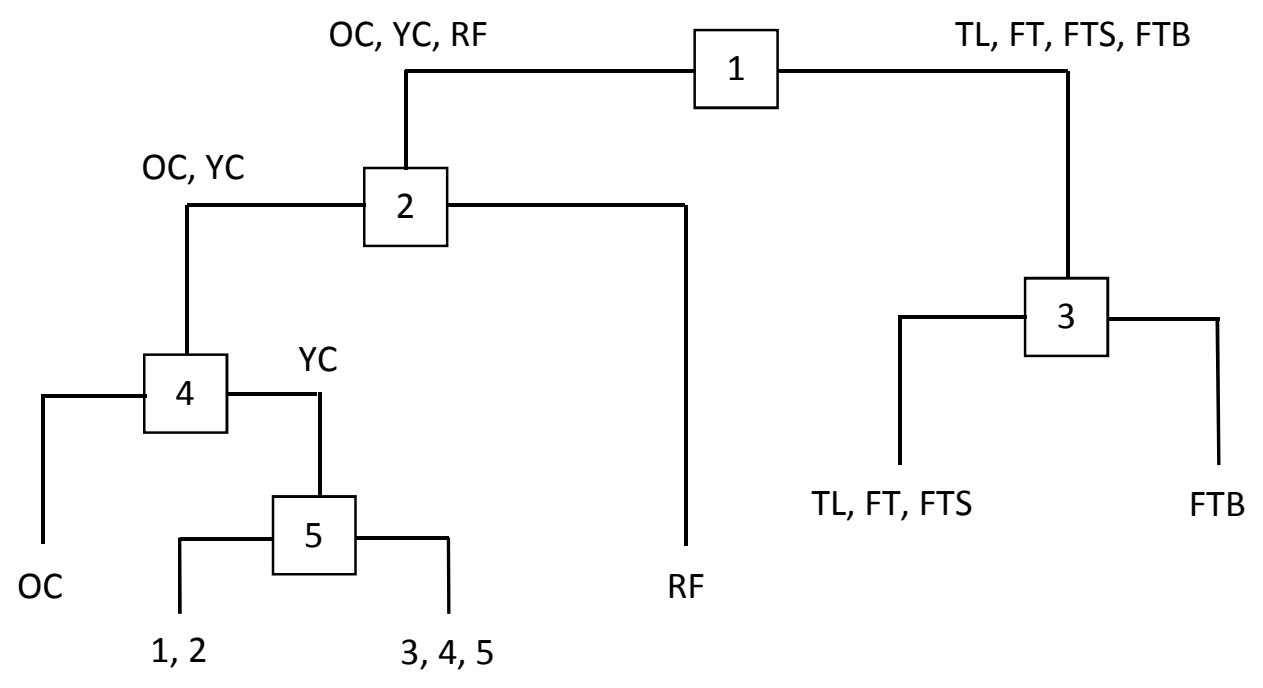


(c)

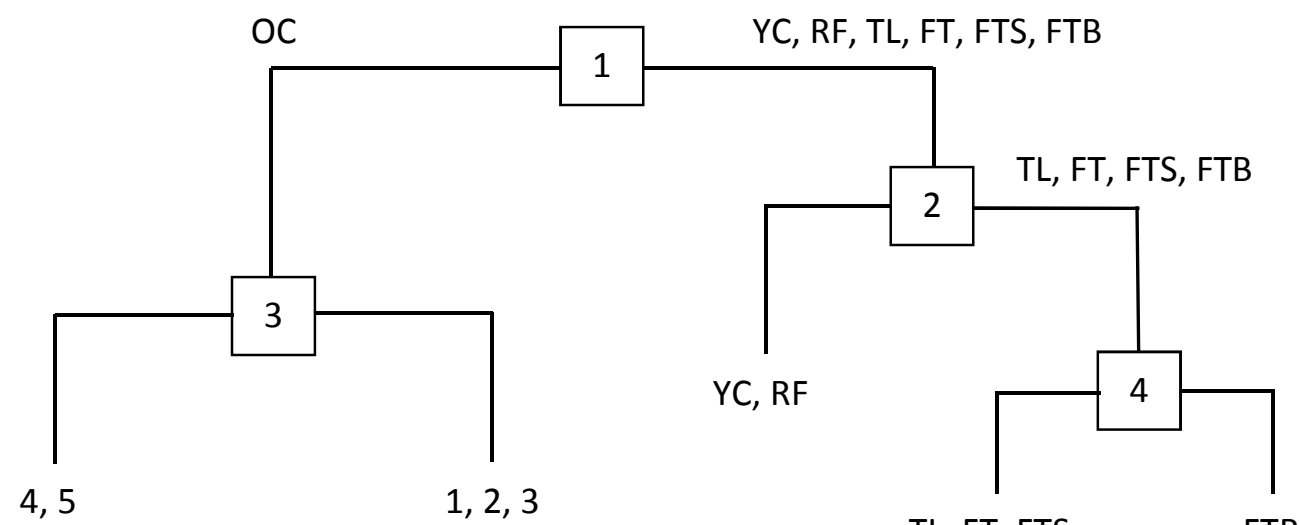


Figure 4

(a)
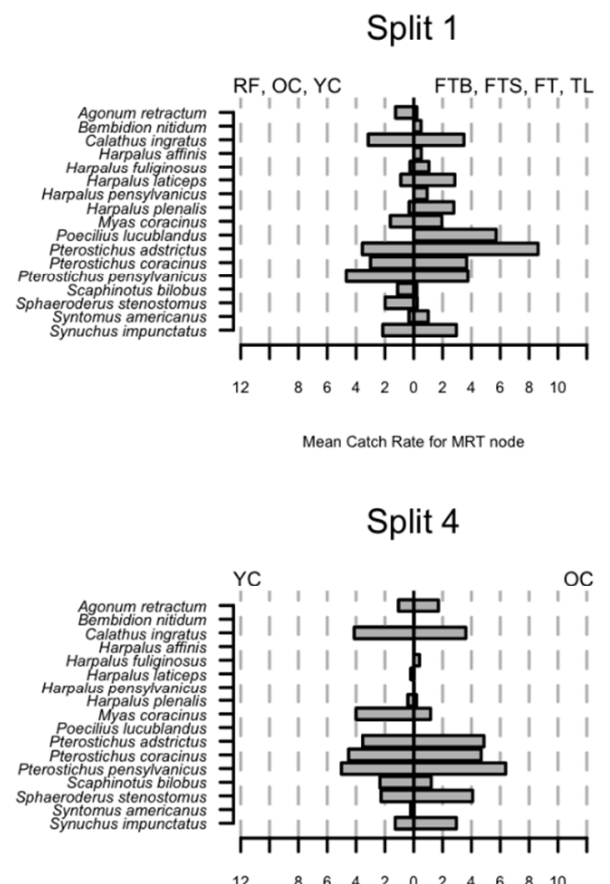

Mean Catch Rate for MRT node

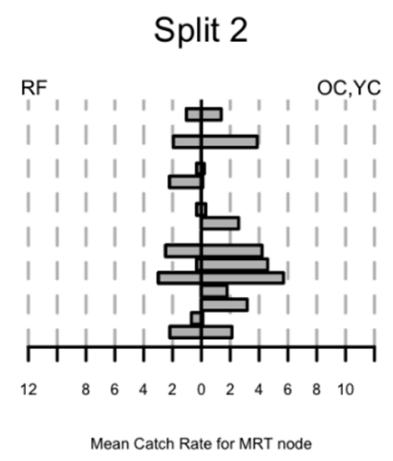

Split 5

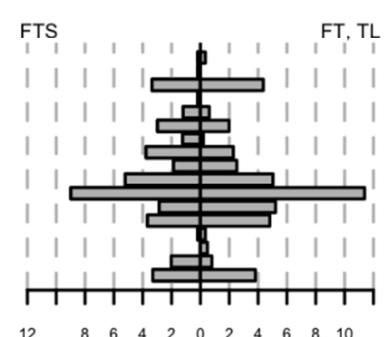

Mean Catch Rate for MRT node
Split 3

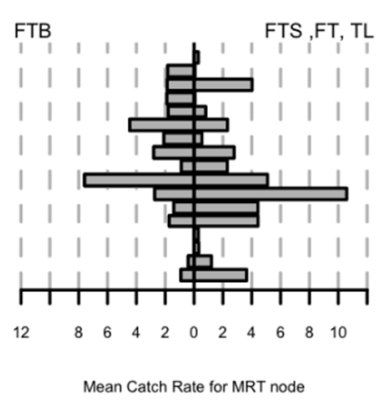

Mean Catch Rate for MRT node 
(b)

Split 1

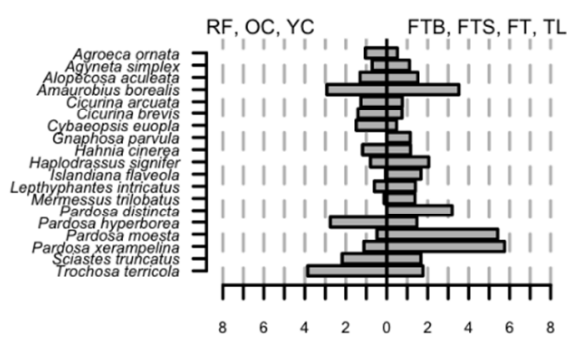

Mean Catch Rate for MRT node

Split 4

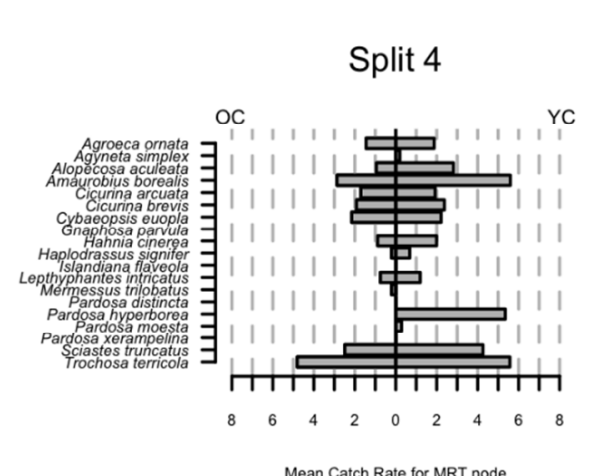

Mean Catch Rate for MRT node
Split 2

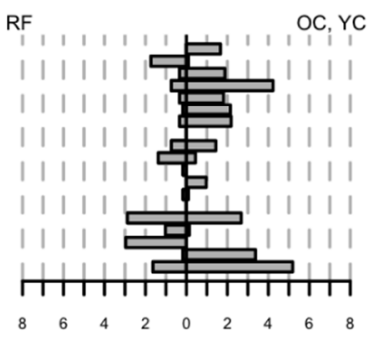

Mean Catch Rate for MRT node

Split 5

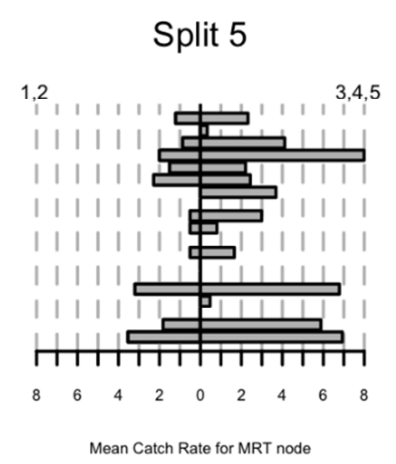

Split 3

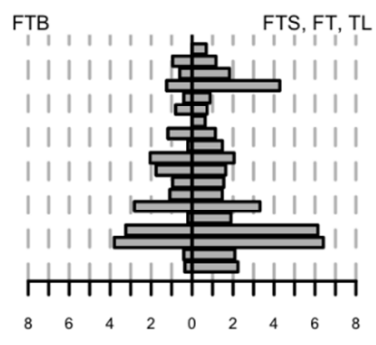

Mean Catch Rate for MRT node 
(c)

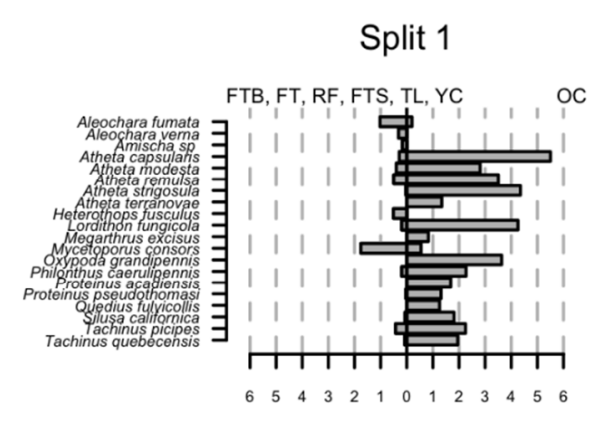

Mean Catch Rate for MRT node

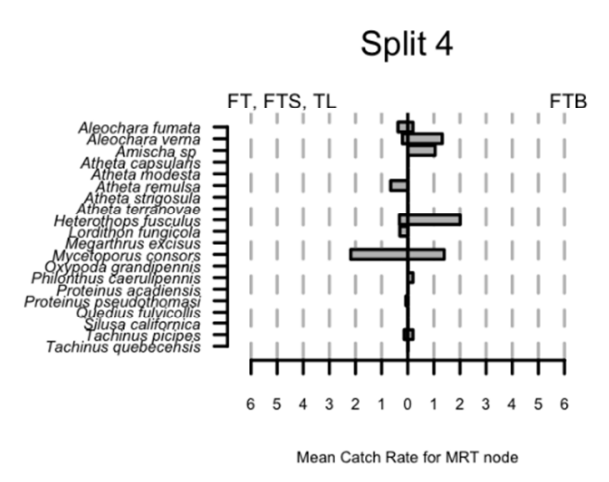

Split 2

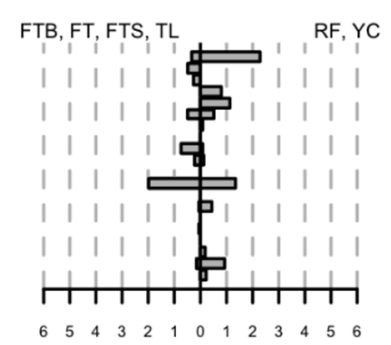

Mean Catch Rate for MRT node
Split 3

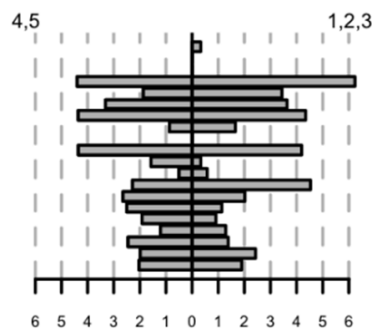

Mean Catch Rate for MRT node 
Figure 5

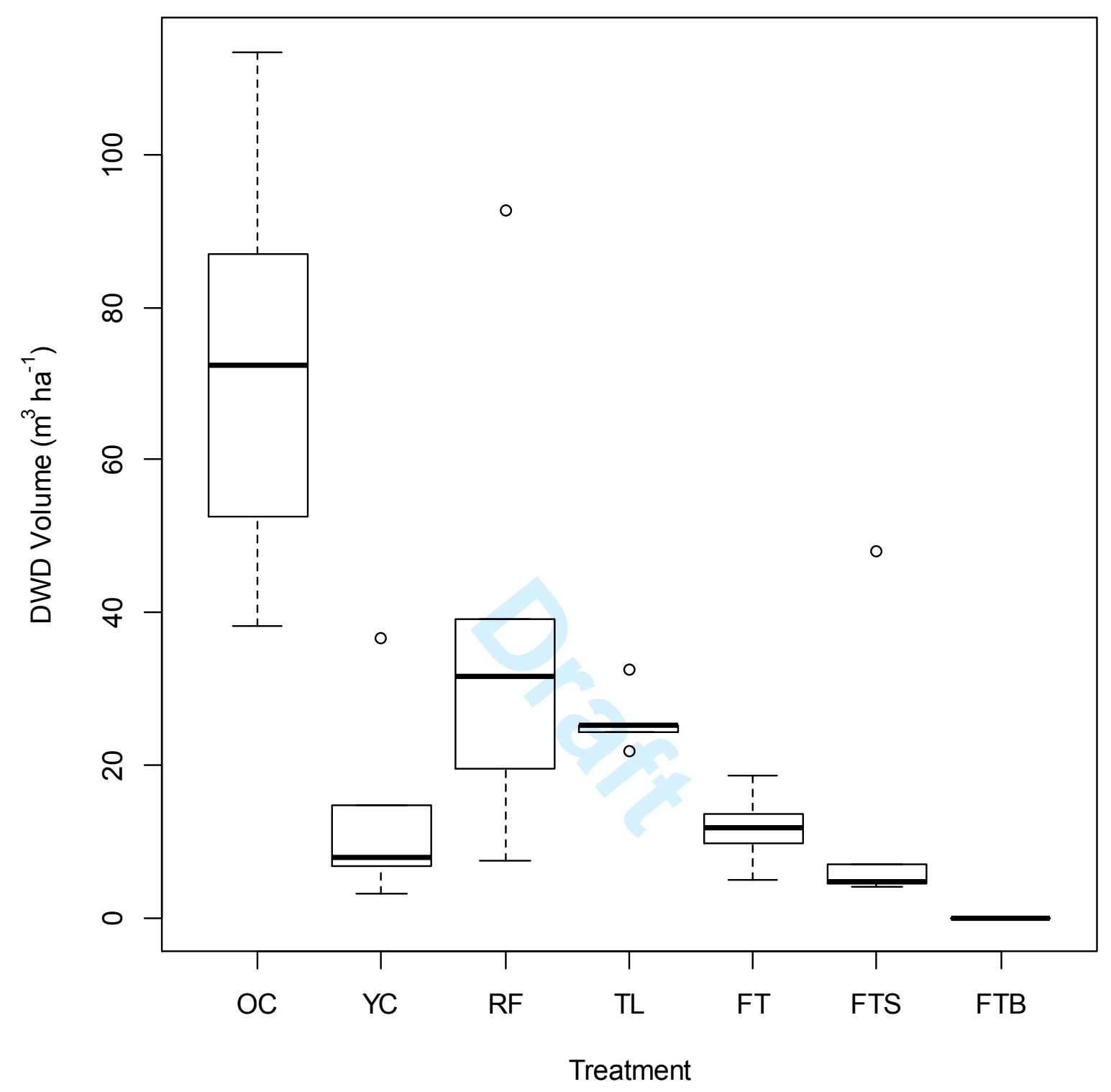


Figure 6

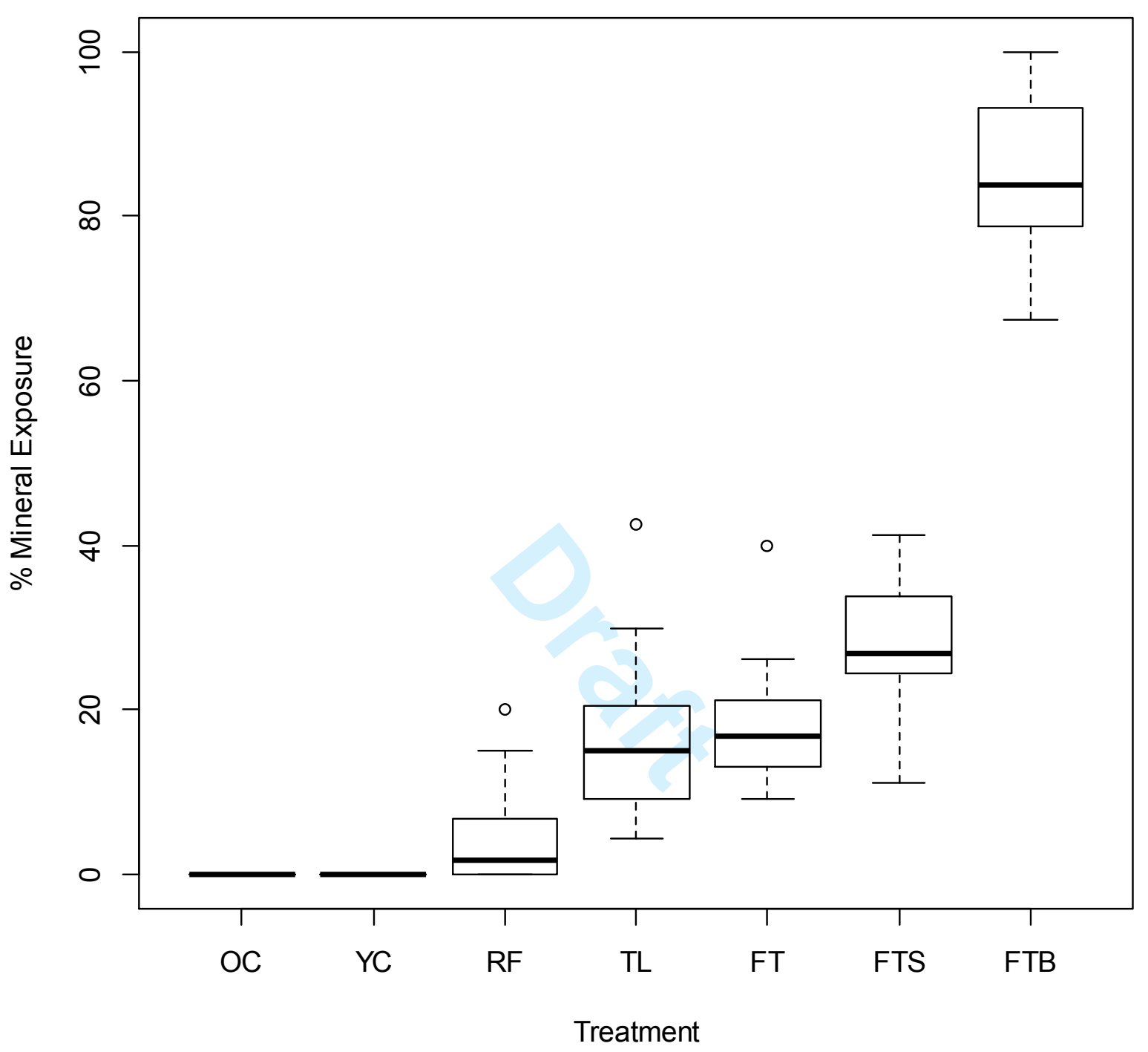

https://mc06.manuscriptcentral.com/cjfr-pubs 
Figure 7

(a)

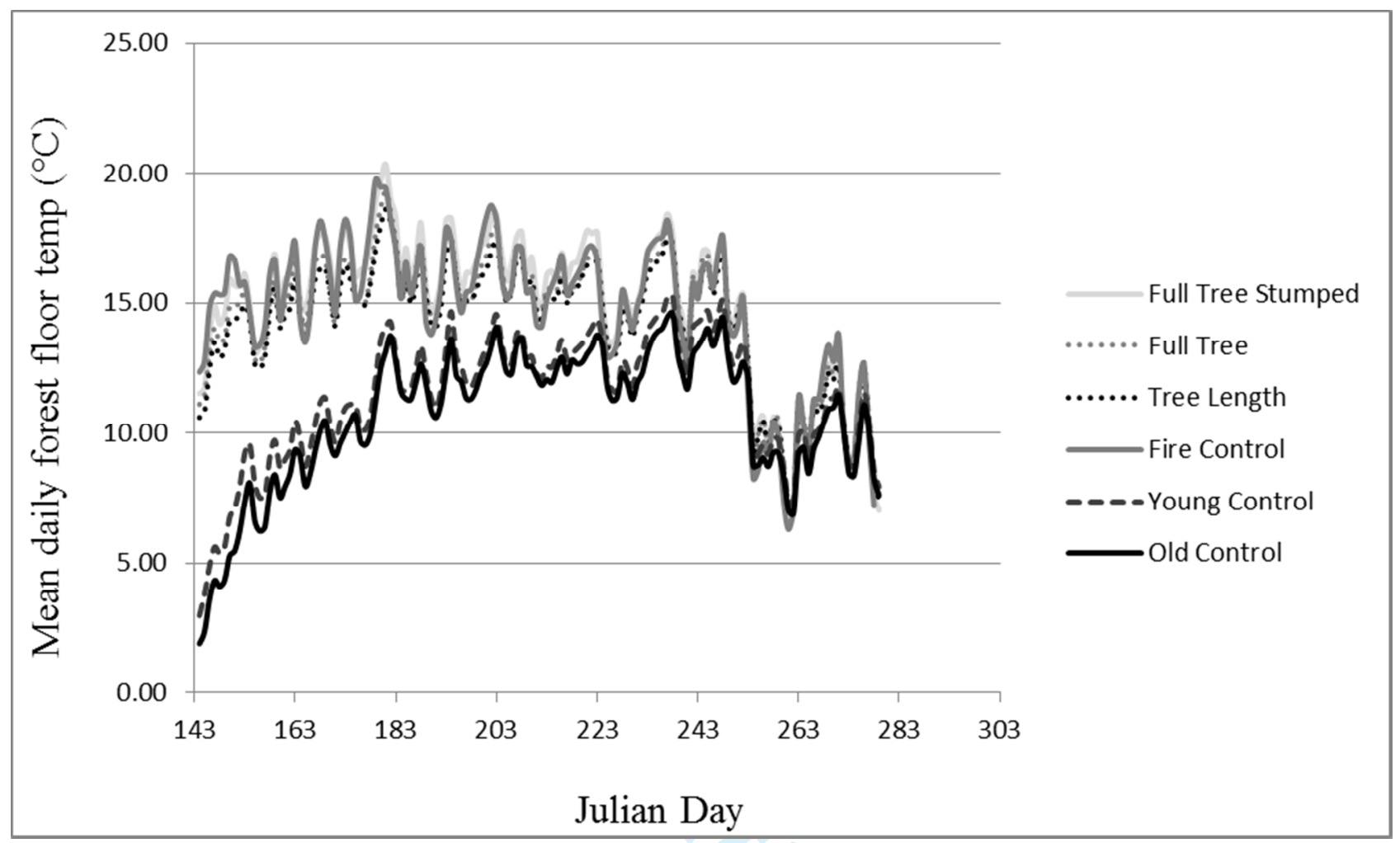


(b)

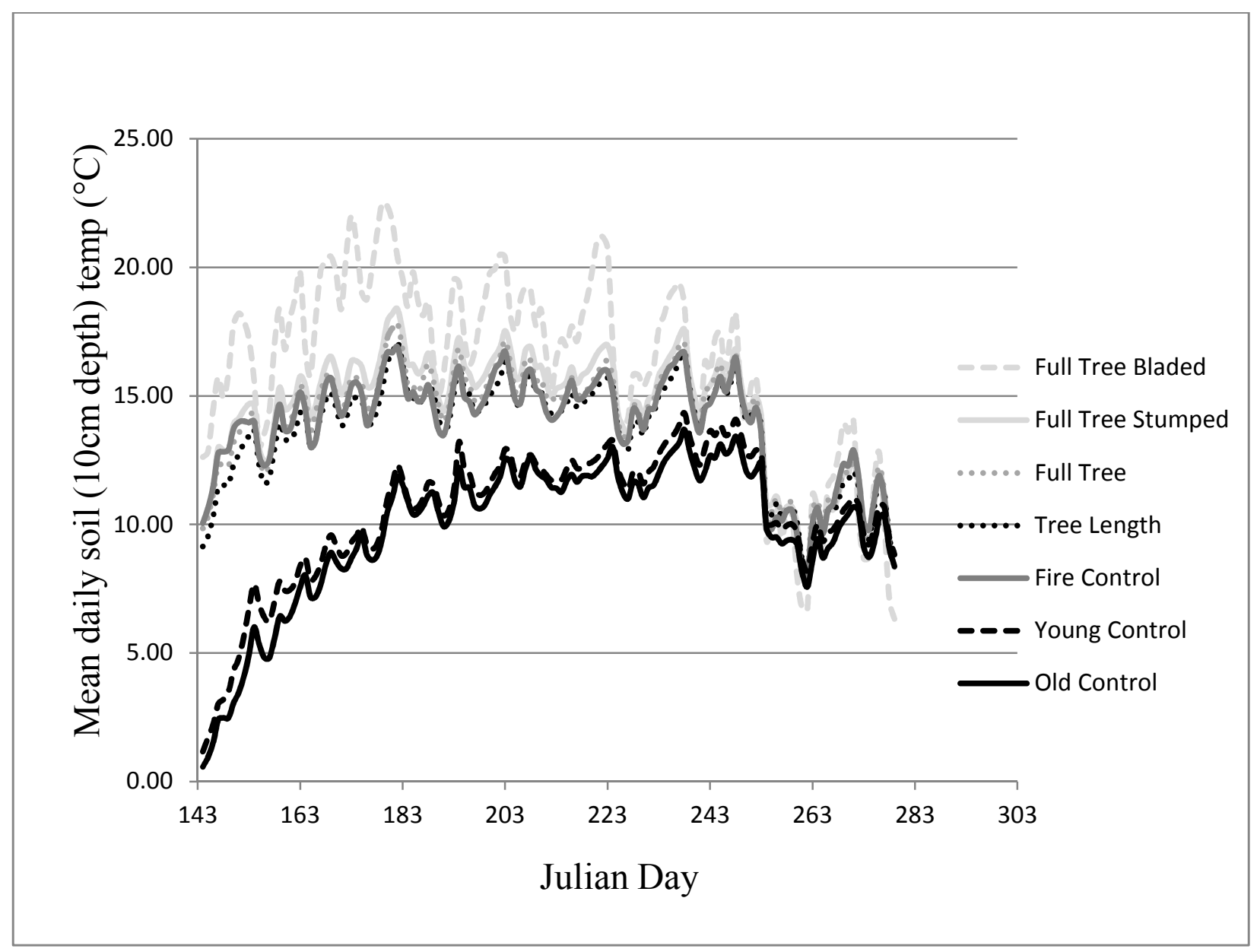


(c)

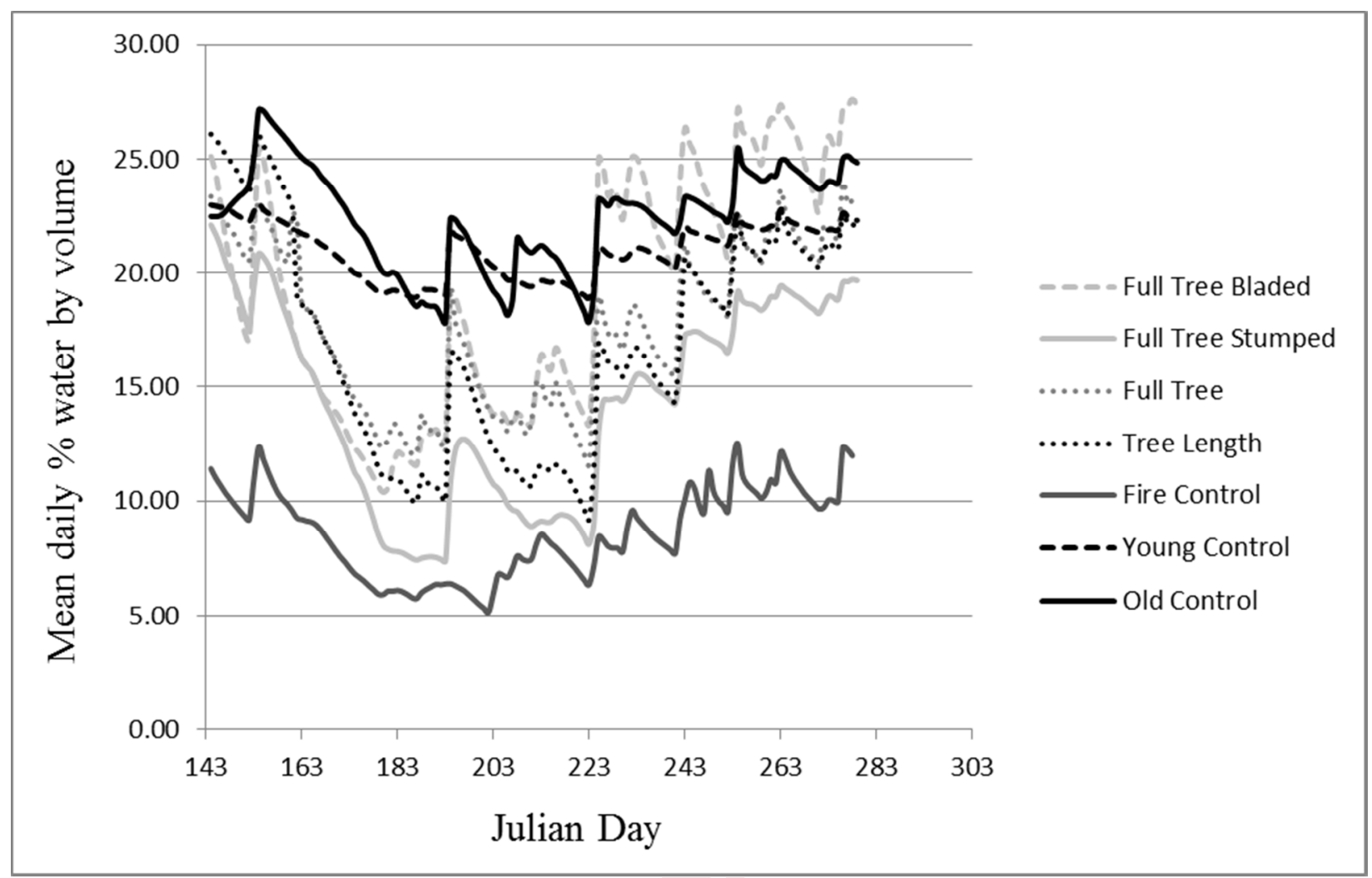


1 Appendix 1: Carabid species list, abundance and \% representation of all carabids.

\begin{tabular}{|c|c|c|}
\hline Species & Abundance & \%Representation \\
\hline Agonum cupripenne & 5 & $0.1 \%$ \\
\hline Agonum retractum & 43 & $0.7 \%$ \\
\hline Amara erratica & 4 & $0.1 \%$ \\
\hline Badister obtustus & 1 & $0.0 \%$ \\
\hline Bembidion nitidum & 18 & $0.3 \%$ \\
\hline Bembidion quadrimaculata & 5 & $0.1 \%$ \\
\hline Calathus ingratus & 470 & $7.9 \%$ \\
\hline Calosoma calidum & 18 & $0.3 \%$ \\
\hline Calosoma frigidum & 4 & $0.1 \%$ \\
\hline Carabus serratus & 12 & $0.2 \%$ \\
\hline Cymindis cribricollis & 8 & $0.1 \%$ \\
\hline Dromius piceus & 1 & $0.0 \%$ \\
\hline Harpalus affinis & 19 & $0.3 \%$ \\
\hline Harpalus egregius & 2 & $0.0 \%$ \\
\hline Harpalus fuliginosus & 38 & $0.6 \%$ \\
\hline Harpalus fulvilabris & 28 & $0.5 \%$ \\
\hline Harpalus laticeps & 230 & $3.9 \%$ \\
\hline Harpalus megacephalus & 20 & $0.3 \%$ \\
\hline Harpalus pensylvanicus & 36 & $0.6 \%$ \\
\hline Harpalus plenalis & 209 & $3.5 \%$ \\
\hline Harpalus sp. & 5 & $0.1 \%$ \\
\hline Myas coracinus & 196 & $3.3 \%$ \\
\hline
\end{tabular}


2

\begin{tabular}{lll} 
Notiophilus aeneus & 4 & $0.1 \%$ \\
Platynus decentis & 11 & $0.2 \%$ \\
Poecilius lucublandus & 703 & $11.9 \%$ \\
Pterostichus adstrictus & 2002 & $33.8 \%$ \\
Pterostichus chalcites & 1 & $0.0 \%$ \\
Pterostichus coracinus & 592 & $10.0 \%$ \\
Pterostichus pensylvanicus & 725 & $12.2 \%$ \\
Pterostichus punctatissimus & 6 & $0.1 \%$ \\
Scaphinotus bilobus & 47 & $0.8 \%$ \\
Sphaeroderus stenostomus & 119 & $2.0 \%$ \\
Syntomus americanus & 41 & $0.7 \%$ \\
Synuchus impunctatus & 300 & $5.1 \%$ \\
\hline
\end{tabular}

2 
7 Appendix 2: Spider species list with abundance and \% representation of all spiders.

\begin{tabular}{|c|c|c|}
\hline Species & Abundance & \% Representation \\
\hline Agroeca ornata & 46 & $0.9 \%$ \\
\hline Agyneta simplex & 53 & $1.1 \%$ \\
\hline Alopecosa aculeata & 124 & $2.6 \%$ \\
\hline Amaurobius borealis & 553 & $11.4 \%$ \\
\hline Aphileta misera & 4 & $0.1 \%$ \\
\hline Arctosa emertoni & 23 & $0.5 \%$ \\
\hline Bassaniana utahensis & 1 & $0.0 \%$ \\
\hline Bathyphantes pallidus & 5 & $0.1 \%$ \\
\hline Callobius bennetti & 39 & $0.8 \%$ \\
\hline Centromerus furcatus & 5 & $0.1 \%$ \\
\hline Ceraticelus fissiceps & 2 & $0.0 \%$ \\
\hline Ceraticelus laetabilis & 4 & $0.1 \%$ \\
\hline Ceraticelus minutus & 6 & $0.1 \%$ \\
\hline Ceraticelus similis & 1 & $0.0 \%$ \\
\hline Ceratinella brunnea & 1 & $0.0 \%$ \\
\hline Ceratinops crenatus & 4 & $0.1 \%$ \\
\hline Cercidia prominens & 6 & $0.1 \%$ \\
\hline Cicurina arcuata & 56 & $1.2 \%$ \\
\hline Cicurina brevis & 72 & $1.5 \%$ \\
\hline Clubiona bishopi & 2 & $0.0 \%$ \\
\hline Clubiona canadensis & 1 & $0.0 \%$ \\
\hline Clubiona kastoni & 7 & $0.1 \%$ \\
\hline
\end{tabular}




\begin{tabular}{|c|c|c|}
\hline Clubiona kulczynskii & 6 & $0.1 \%$ \\
\hline Crustulina sticta & 6 & $0.1 \%$ \\
\hline Cryphoeca montana & 5 & $0.1 \%$ \\
\hline Cybaeopsis euopla & 84 & $1.7 \%$ \\
\hline Dictyna coloradensis & 3 & $0.1 \%$ \\
\hline Diplocentria bidentata & 23 & $0.5 \%$ \\
\hline Diplocentria retinax & 12 & $0.2 \%$ \\
\hline Diplocephalus cristatus & 1 & $0.0 \%$ \\
\hline Drassodes neglectus & 22 & $0.5 \%$ \\
\hline Drassyllus niger & 2 & $0.0 \%$ \\
\hline Erigone atra & 3 & $0.1 \%$ \\
\hline Euryopis argentea & 3 & $0.1 \%$ \\
\hline Evarcha hoyi & 8 & $0.2 \%$ \\
\hline Floricomus plumalis & 2 & $0.0 \%$ \\
\hline Gnaphosa muscorum & 35 & $0.7 \%$ \\
\hline Gnaphosa parvula & 35 & $0.7 \%$ \\
\hline Grammonota angusta & 1 & $0.0 \%$ \\
\hline Habronattus waughi & 1 & $0.0 \%$ \\
\hline Hahnia cinerea & 88 & $1.8 \%$ \\
\hline Halorates plumosus & 2 & $0.0 \%$ \\
\hline Haplodrassus eunis & 2 & $0.0 \%$ \\
\hline Haplodrassus hiemalis & 10 & $0.2 \%$ \\
\hline Haplodrassus signifer & 114 & $2.3 \%$ \\
\hline Hogna frondicola & 17 & 0.3 \\
\hline
\end{tabular}




\begin{tabular}{|c|c|c|}
\hline Hybauchenidium & 1 & $0.0 \%$ \\
\hline \multicolumn{3}{|l|}{ cymbadentatum } \\
\hline Hypselistes florens & 3 & $0.1 \%$ \\
\hline Improphantes complicatus & 2 & $0.0 \%$ \\
\hline Islandiana flaveola & 68 & $1.4 \%$ \\
\hline Lathys pallida & 49 & $1.0 \%$ \\
\hline Lepthyphantes intricatus & 68 & $1.4 \%$ \\
\hline Mermessus maculatus & 21 & $0.4 \%$ \\
\hline Mermessus trilobatus & 49 & $1.0 \%$ \\
\hline Micaria aenea & 2 & $0.0 \%$ \\
\hline Micaria pulicaria & 10 & $0.2 \%$ \\
\hline Micrargus longitarsus & 2 & $0.0 \%$ \\
\hline Neon nellii & 10 & $0.2 \%$ \\
\hline Neriene radiata & 3 & $0.1 \%$ \\
\hline Ostearius melanopygius & 1 & $0.0 \%$ \\
\hline Ozyptila sincera canadensis & 8 & $0.2 \%$ \\
\hline Pardosa concinna & 3 & $0.1 \%$ \\
\hline Pardosa distincta & 226 & $4.6 \%$ \\
\hline Pardosa fuscula & 1 & $0.0 \%$ \\
\hline Pardosa hyperborea & 310 & $6.4 \%$ \\
\hline Pardosa mackenziana & 31 & $0.6 \%$ \\
\hline Pardosa milvina & 7 & $0.1 \%$ \\
\hline Pardosa modica & 1 & $0.0 \%$ \\
\hline Pardosa moesta & 721 & $14.8 \%$ \\
\hline
\end{tabular}




\begin{tabular}{|c|c|c|}
\hline Pardosa xerampelina & 803 & $16.5 \%$ \\
\hline Pelegrina flavipes & 3 & $0.1 \%$ \\
\hline Philodromus imbecillus & 1 & $0.0 \%$ \\
\hline Philodromus rufus & 7 & $0.1 \%$ \\
\hline Phrurotimpus certus & 11 & $0.2 \%$ \\
\hline Pirata canadensis & 1 & $0.0 \%$ \\
\hline Pirata minutus & 5 & $0.1 \%$ \\
\hline Pocadicnemis americana & 21 & $0.4 \%$ \\
\hline Porrhomma terrestre & 3 & $0.1 \%$ \\
\hline Robertus fuscus & 1 & $0.0 \%$ \\
\hline Robertus riparius & 25 & $0.5 \%$ \\
\hline Rugathodes aurantius & 1 & $0.0 \%$ \\
\hline Sciastes truncatus & 222 & $4.6 \%$ \\
\hline Scotinella pugnata & 1 & $0.0 \%$ \\
\hline Scotinotylus pallidus & 4 & $0.1 \%$ \\
\hline Scyletria inflata & 1 & $0.0 \%$ \\
\hline Sibianor aemulus & 3 & $0.1 \%$ \\
\hline Sisicottus montanus & 1 & $0.0 \%$ \\
\hline Souessa spinifera & 2 & $0.0 \%$ \\
\hline Steatoda albomaculata & 10 & $0.2 \%$ \\
\hline Styloctetor stativus & 2 & $0.0 \%$ \\
\hline Tapinocyba minuta & 30 & $0.6 \%$ \\
\hline Tapinocyba simplex & 11 & $0.2 \%$ \\
\hline Tennesseellum formicum & 7 & $0.1 \%$ \\
\hline
\end{tabular}




\begin{tabular}{|c|c|c|}
\hline Tenuiphantes zebra & 5 & $0.1 \%$ \\
\hline Tetragnatha laboriosa & 1 & $0.0 \%$ \\
\hline Thanatus formicinus & 12 & $0.2 \%$ \\
\hline Thanatus striatus & 2 & $0.0 \%$ \\
\hline Theonoe stridula & 5 & $0.1 \%$ \\
\hline Trochosa terricola & 394 & $8.1 \%$ \\
\hline Tunagyna debilis & 7 & $0.1 \%$ \\
\hline Tutelina similis & 2 & $0.0 \%$ \\
\hline Walckenaeria castanea & 2 & $0.0 \%$ \\
\hline Walckenaeria communis & 1 & $0.0 \%$ \\
\hline Walckenaeria digitata & 14 & $0.3 \%$ \\
\hline Walckenaeria directa & 6 & $0.1 \%$ \\
\hline Walckenaeria exigua & 8 & $0.2 \%$ \\
\hline Walckenaeria spiralis & 2 & $0.0 \%$ \\
\hline Xysticus canadensis & 1 & $0.0 \%$ \\
\hline Xysticus discursans & 2 & $0.0 \%$ \\
\hline Xysticus elegans & 14 & $0.3 \%$ \\
\hline Xysticus emertoni & 4 & $0.1 \%$ \\
\hline Xysticus luctuosus & 3 & $0.1 \%$ \\
\hline Xysticus montanensis & 10 & $0.2 \%$ \\
\hline Xysticus obscurus & 12 & $0.2 \%$ \\
\hline Xysticus punctatus & 2 & $0.0 \%$ \\
\hline Xysticus triguttatus & 5 & $0.1 \%$ \\
\hline Zelotes fratris & 64 & $1.3 \%$ \\
\hline
\end{tabular}


8

Zelotes puritanus

10

$0.2 \%$

8 
10 Appendix 3: Staphylinidae species list with total abundance and \% representation of all rove beetles.

\begin{tabular}{|c|c|c|}
\hline Species & Abundance & \% Represetnation \\
\hline Achenomorphus corticinus & 1 & $0.1 \%$ \\
\hline Acidota crenata & 3 & $0.2 \%$ \\
\hline Acidota subcarinata & 12 & $1.0 \%$ \\
\hline Aleochara fumata & 79 & $6.4 \%$ \\
\hline Aleochara verna & 14 & $1.1 \%$ \\
\hline Amischa sp. & 7 & $0.6 \%$ \\
\hline Atheta brunswickensis & 5 & $0.4 \%$ \\
\hline Atheta capsularis & 169 & $13.7 \%$ \\
\hline Atheta dadopora & 7 & $0.6 \%$ \\
\hline Atheta frosti & 7 & $0.6 \%$ \\
\hline Atheta modesta & 61 & $5.0 \%$ \\
\hline Atheta pennsylvanica & 20 & $1.6 \%$ \\
\hline Atheta pseudosubtilis & 11 & $0.9 \%$ \\
\hline Atheta remulsa & 89 & $7.2 \%$ \\
\hline Atheta sp. & 4 & $0.3 \%$ \\
\hline Atheta strigosula & 96 & $7.8 \%$ \\
\hline Atheta terranovae & 12 & $1.0 \%$ \\
\hline Atheta ventricosa & 1 & $0.1 \%$ \\
\hline Athetini sp. & 6 & $0.5 \%$ \\
\hline Bolitobius cingulatus & 2 & $0.2 \%$ \\
\hline Byroporus rufescens & 1 & $0.1 \%$ \\
\hline Carphacis nepigonensis & 3 & $0.2 \%$ \\
\hline
\end{tabular}




\begin{tabular}{|c|c|c|}
\hline Dinaraea pacei & 1 & $0.1 \%$ \\
\hline Eusphalerum pothos & 6 & $0.5 \%$ \\
\hline Gabrius microphthalmus & 15 & $1.2 \%$ \\
\hline Heterothops fusculus & 29 & $2.4 \%$ \\
\hline Heterothops minor & 1 & $0.1 \%$ \\
\hline Heterothops sp. & 3 & $0.2 \%$ \\
\hline Ischnosoma fimbriatum & 4 & $0.3 \%$ \\
\hline Ischnosoma pictum & 7 & $0.6 \%$ \\
\hline Lathrobium washingtoni & 3 & $0.2 \%$ \\
\hline Leptusa breuvicollis & 1 & $0.1 \%$ \\
\hline Liogluta granulosa & 2 & $0.2 \%$ \\
\hline Lordithon facilis & 3 & $0.2 \%$ \\
\hline Lordithon fungicola & 100 & $8.1 \%$ \\
\hline Megarthrus excisus & 6 & $0.5 \%$ \\
\hline Mycetoporus consors & 118 & $9.6 \%$ \\
\hline Mycetoporus sp. & 2 & $0.2 \%$ \\
\hline Nitidulidae sp. & 1 & $0.1 \%$ \\
\hline Omalium sp. & 4 & $0.3 \%$ \\
\hline Ontholestes cingulatus & 1 & $0.1 \%$ \\
\hline Oxypoda convergens & 2 & $0.2 \%$ \\
\hline Oxypoda grandipennis & 74 & $6.0 \%$ \\
\hline Oxypoda orbicollis & 1 & $0.1 \%$ \\
\hline Oxypoda pseudolacustris & 3 & $0.2 \%$ \\
\hline Oxyporus vittatus & 1 & $0.1 \%$ \\
\hline
\end{tabular}




\begin{tabular}{|c|c|c|}
\hline Paederus littorarius & 1 & $0.1 \%$ \\
\hline Philonthus caerulipennis & 34 & $2.8 \%$ \\
\hline Philonthus couleensis & 1 & $0.1 \%$ \\
\hline Proteinus acadiensis & 21 & $1.7 \%$ \\
\hline Proteinus parvulus & 1 & $0.1 \%$ \\
\hline Proteinus pseudothomasi & 14 & $1.1 \%$ \\
\hline Pseudopsis subulata & 2 & $0.2 \%$ \\
\hline Quedius fulvicollis & 11 & $0.9 \%$ \\
\hline Quedius labradorensis & 15 & $1.2 \%$ \\
\hline Quedius rusticus & 2 & $0.2 \%$ \\
\hline Silusa californica & 20 & $1.6 \%$ \\
\hline Silusida marginella & 6 & $0.5 \%$ \\
\hline Stenus sp. & 3 & $0.2 \%$ \\
\hline Strophogastra penicillata & 1 & $0.1 \%$ \\
\hline Tachinus addendus & 3 & $0.2 \%$ \\
\hline Tachinus fumipennis & 1 & $0.1 \%$ \\
\hline Tachinus luridus & 3 & $0.2 \%$ \\
\hline Tachinus memnonius & 5 & $0.4 \%$ \\
\hline Tachinus picipes & 53 & $4.3 \%$ \\
\hline Tachinus quebecensis & 23 & $1.9 \%$ \\
\hline Tachyporus dispar & 10 & $0.8 \%$ \\
\hline Tachyporus nitidulus & 1 & $0.1 \%$ \\
\hline Tympanophorus puncticollis & 1 & $0.1 \%$ \\
\hline Zyras obliques & 1 & $0.1 \%$ \\
\hline
\end{tabular}


12

11 Appendix 4: Mean (Standard Error) values for Environmental variables.

\begin{tabular}{llllllll}
\hline Variable & $\begin{array}{l}\text { Old } \\
\text { Control } \\
(\mathrm{OC})\end{array}$ & $\begin{array}{l}\text { Young } \\
\text { Control } \\
(\mathrm{YC})\end{array}$ & $\begin{array}{l}\text { Recent } \\
\text { Fire (RF) }\end{array}$ & $\begin{array}{l}\text { Stem-only } \\
(\mathrm{SO})\end{array}$ & $\begin{array}{l}\text { Full-tree } \\
(\mathrm{FT})\end{array}$ & $\begin{array}{l}\text { Full-tree } \\
\text { Stumped } \\
(\mathrm{FTS})\end{array}$ & $\begin{array}{l}\text { Full-tree } \\
\text { Bladed } \\
(\mathrm{FTB})\end{array}$ \\
\hline $\begin{array}{l}\text { Total CWD } \\
\left(\mathrm{m}^{3} / \mathrm{ha}\right)\end{array}$ & $\begin{array}{l}72.72 \\
(13.13)\end{array}$ & $9.82(6.52)$ & $\begin{array}{l}36.16 \\
(14.21)\end{array}$ & $\begin{array}{l}17.02 \\
(0.72)\end{array}$ & $9.74(2.03)$ & $4.46(1.73)$ & $0.00(0.00)$ \\
Soil & $0.00(0.00)$ & $0.00(0.00)$ & $5.14(2.58)$ & 16.30 & 17.92 & 27.94 & 85.74 \\
$\begin{array}{l}\text { Exposure } \\
(\%)\end{array}$ & & & & $(3.26)$ & $(2.01)$ & $(2.34)$ & $(3.75)$ \\
\end{tabular}

12

13

14 
15 Appendix 5: Tukey multiple comparisons of treatments for Total Coarse Woody Debris and 16 Mineral Soil Exposure.

\begin{tabular}{lllll}
\hline Treatment & \multicolumn{2}{l}{ Total CWD } & & \multicolumn{2}{l}{ Mineral Soil Exposure } \\
\cline { 2 - 5 } Comparison & z-value & P-value & z-value & P-value \\
\hline OC-YC & 5.712 & 0.001 & 0.000 & 1.000 \\
OC-RF & 3.320 & 0.016 & 1.547 & 0.716 \\
OC-SO & 5.058 & 0.001 & -4.904 & $<0.001$ \\
OC-FT & 5.719 & 0.001 & -5.392 & $<0.001$ \\
OC-FTS & 6.199 & 0.001 & -8.407 & $<0.001$ \\
OC-FTB & 6.604 & 0.001 & -25.798 & $<0.001$ \\
YC-RF & -2.392 & 0.202 & -1.547 & 0.716 \\
YC-SO & 0.654 & 0.995 & -4.904 & $<0.001$ \\
YC-FT & 0.007 & 1.000 & -5.392 & $<0.001$ \\
YC-FTS & 0.487 & 0.999 & -8.407 & $<0.001$ \\
YC-FTB & 0.892 & 0.974 & -25.798 & $<0.001$ \\
RF-SO & 1.738 & 0.590 & -3.358 & 0.014 \\
RF-FT & 2.399 & 0.199 & -3.845 & 0.002 \\
RF-FTS & 2.879 & 0.061 & -6.860 & $<0.001$ \\
RF-FTB & 3.284 & 0.018 & -24.251 & $<0.001$ \\
SO-FT & 0.661 & 0.995 & -0.487 & 0.999 \\
SO-FTS & 1.141 & 0.916 & -3.502 & 0.008 \\
SO-FTB & 1.546 & 0.717 & -20.893 & $<0.001$ \\
FT-FTS & 0.479 & 0.999 & -3.015 & 0.041 \\
FT-FTB & 0.884 & 0.975 & -20.406 & $<0.001$ \\
FTS-FTB & 0.405 & 1.000 & -17.391 & $<0.001$ \\
\hline
\end{tabular}

17

18 